\title{
Evolution in the provenance of a tectonically controlled Plio-Pleistocene alluvial system between the Variscan Iberian Massif and the Atlantic margin, Portugal
}

\author{
Pedro A. Dinis ${ }^{\mathrm{a}, *}$, Álvaro Oliveira ${ }^{\mathrm{b}}$, Fernando Rocha ${ }^{\mathrm{c}}$, Manuel Vieira $^{\mathrm{d}}$, Pedro P. Cunha ${ }^{\mathrm{a}}$ \\ a Department of Earth Sciences/Institute of Marine Sciences (IMAR-CIC), University of Coimbra, Portugal \\ ${ }^{\mathrm{b}}$ Laboratório do INETI de S. Mamede Infesta, Porto, Portugal \\ ${ }^{c}$ Geobiotec Centre/Department of Geosciences, University of Aveiro, Portugal \\ d Centro de Geologia da Universidade do Porto, Universidade do Minho, Portugal
}

\section{A R T I C L E I N F O}

\section{Article history:}

Received 10 May 2010

Accepted 5 December 2010

\section{Keywords:}

Provenance

Floodplain

Swamp-lake

Tectonics

Geochemistry

REE

Clay mineralogy

\begin{abstract}
A B S T R A C T
Geochemical and mineralogical data from a Pliocene to Pleistocene alluvial sequence are integrated to access the factors that control rare earth elements (REE) geochemistry and the evolution and spatial differences in provenance. The studied alluvial system is situated in a tectonic active setting at the contact between the Variscan Massif, with several Paleozoic and Precambrian units that support a coastal range, and the Atlantic margin. REE and HREE abundances are generally higher in swamp-lake than in floodplain sediments. The majority of the REE in floodplain sediments is hosted by Y and Th-bearing minerals and illite; in swamp-lake sediments is also probable an association with organic matter. The high $\mathrm{Gd} / \mathrm{Yb}$, $\mathrm{Eu} / \mathrm{Eu}^{*}$ and kaolinite content in older sediments suggest that during the earlier phases provenance was mainly from the hinterland (weathered granitic rocks and its sediment cover). The subsequent illite (Mg-rich) clay assemblages and REE patterns indicate mainly lateral input from the eastern basin edge (Palaeozoic and Precambrian metapelitic rocks). These sediments tend to have lower Gd/Yb and La/Sm than their source rocks. The analysis of the chemical index of alteration (CIA) indicates that although a north-directed fluvial axis existed at that time the "mature" basin edge units found to the south (Silurian) had a limited role in supplying sediments. This shift in provenance is attributed to the uplift of the coastal range. Afterwards, the contribution of recycled Cretaceous and Cenozoic sedimentary units increased progressively. This is demonstrated by the increase is $\mathrm{SiO}_{2} / \mathrm{TiO}_{2}, \mathrm{CIA}$ and kaolinite/illite when the climatic conditions are expected to have become less chemically aggressive.
\end{abstract}

(C) 2011 Published by Elsevier GmbH.

\section{Introduction}

Sediment composition is influenced by the lithology of source areas, weathering conditions, fractionation processes and postdepositional transformations (Chamley, 1989; McLennan, 1989; Morton and Hallsworth, 1999; López et al., 2005). At catchment scale, the type and rate of weathering and erosion is fundamentally controlled by the nature of the source rocks and climatic conditions. After sediment genesis, fractionation processes, influenced by the size, shape and density of particles, control the mineral assemblages and the geochemistry of the sedimentary deposit. Post-depositional processes affect the original sediments differently and may act during surface sediment storage and diagenesis. Although the composition is controlled by different processes, some trace elements that exhibit relatively immobile behaviour,

* Corresponding author at: Department of Earth Sciences, Largo Marquês de Pombal, 3000-272, Coimbra, Portugal. Tel.: +351 239860 512; fax: +351 239860501.

E-mail address: pdinis@dct.uc.pt (P.A. Dinis). like rare earth elements (REE), are considered useful indicators of provenance, particularly in fine grained sediments (Cullers et al., 1987; McLennan et al., 1993; Bauluz et al., 2000; Gu et al., 2002; López et al., 2005).

The studied Plio-Pleistocene deposits were formed in a small scale basin (Cértima Depression, Dinis and Soares, 2007a) located at the contact between the Variscan Iberian Massif and the Coastal Margin, which is associated with the Porto-Tomar shear zone (Pereira, 1987; Dias and Ribeiro, 1993; Chaminé et al., 2003). This structural corridor was active during the upper Pliocene and Pleistocene and participated in the uplift of a coastal range that separates the hinterland from the coastal margin (Ferreira, 1991; Cabral, 1995). Previous facies analysis (Dinis, 2006) indicates that the alluvial Pliocene to Pleistocene succession was deposited in system that comprised axial-rivers and lateral alluvial fans of variable importance and that the tectonic activity was responsible for the development of distinguishable structural compartments in the coastal margin. However, the role played by tectonics on the evolution of sediment provenance was not assessed before. The studied fine-grained units are of particular importance because they con- 

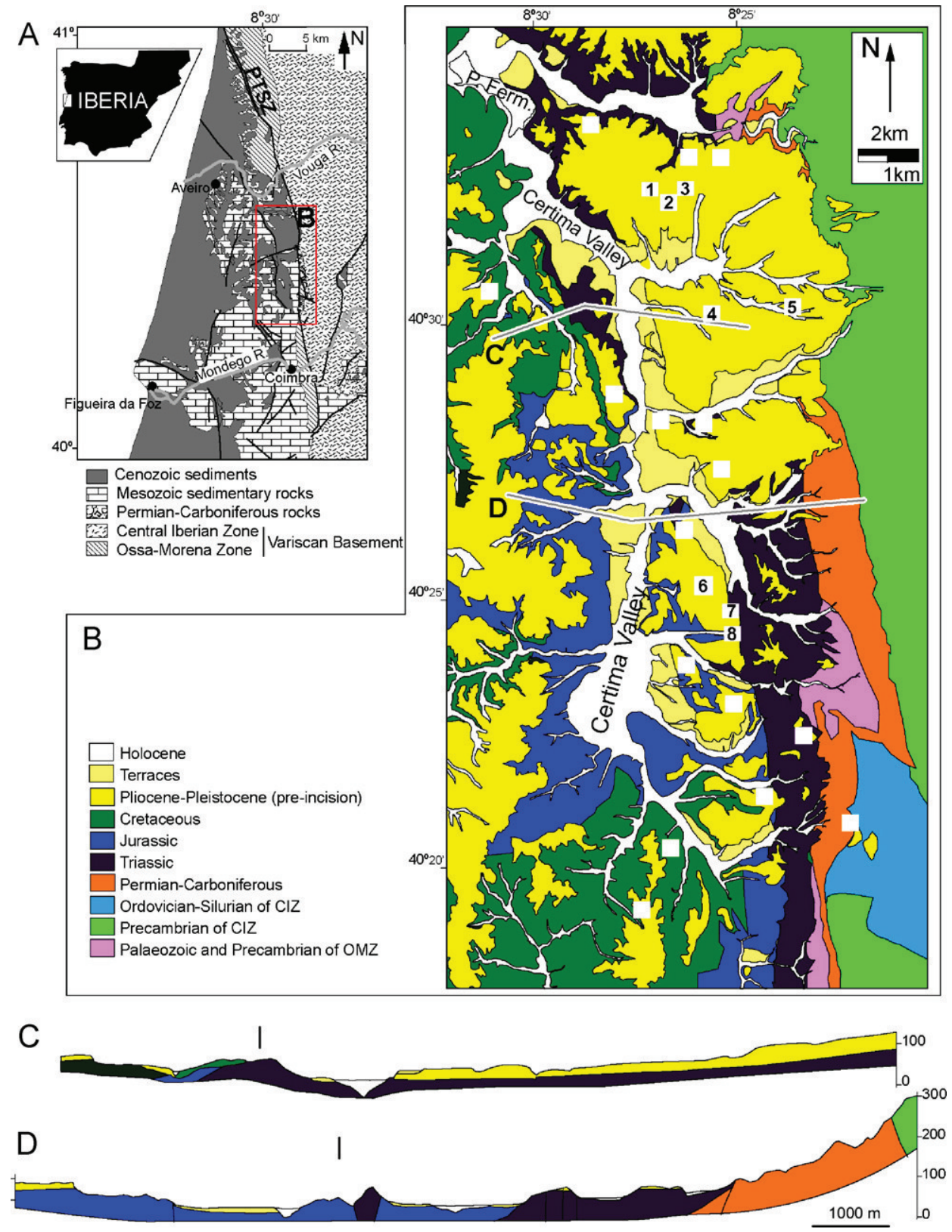

Fig. 1. Geological setting of the studied deposits. (A) Location in West Iberia. PTSZ: Porto-Tomar Shear Zone. (B) Geological map of the study area. Numbered white squares

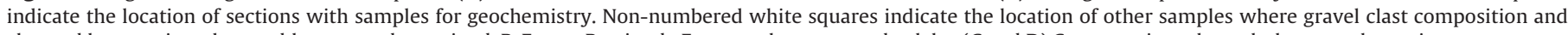
clay and heavy mineral assemblages was determined. P. Ferm.: Pateira de Fermentelos present-day lake. (C and D) Cross-sections through the coastal margin.

tain a relatively continuous record of the changes that occurred during a period of tectonic activity, when the reorganization of the depositional system took place.

This study aims to: (1) comprehend the factors that controlled REE sediment composition; (2) define the evolution in provenance, giving especial attention to the variations in basin edge, hinterland and recycled contributions and the influence of the coastal range uplift in modifying sediment sources; (3) identify the most adequate geochemical data to discern small scale differences in provenance.

\section{Geological setting}

The studied area is located at the contact between the Variscan Iberian Massif (Precambrian to Paleozoic sedimentary and metasedimentary rocks and, further inland, granitoids) and the west Iberia coastal margin (Mesozoic clastic and carbonate sedimentary units) (Fig. 1). An elongated sub-basin that reaches $10 \mathrm{~km}$ wide and $50 \mathrm{~km}$ long (Cértima Depression) contains a Plio-Pleistocene succession (up to $70 \mathrm{~m}$ thick) related to north to northwest-directed axial drainage and lateral alluvial fans. Two of the major morphostructural units of the Variscan Iberian Massif occur in the basin edge: the Central Iberian Zone (CIZ) and the OssaMorena Zone (OMZ). Only sparse patches of the OMZ outcrop in the study area, as they tend to be covered by Mesozoic or Cenozoic deposits. In the basin edge the CIZ includes Precambrian (phylites and metagreywackes) and Ordovician to Silurian units (quartzites, slates and black shales). A Permo-Carboniferous alluvial-lacustrine succession, deposited in a Variscan basin, overlies the OMZ and CIZ and is overthrusted by the $\mathrm{OMZ}$ at least in the western edge.

It is possible to differentiate a western uplifted sector where the sedimentary record is relatively thin (usually less than $10 \mathrm{~m}$ ), and 


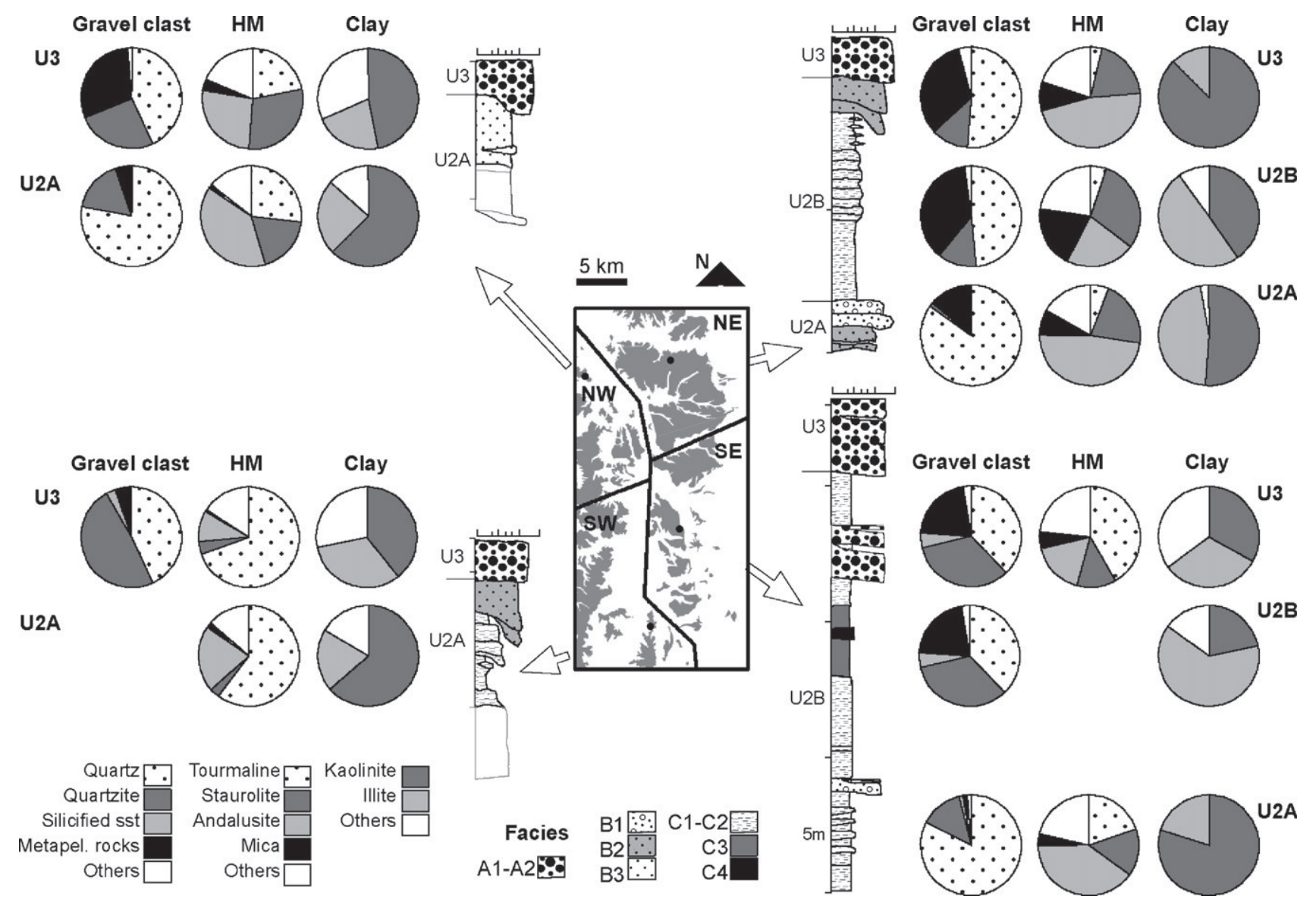

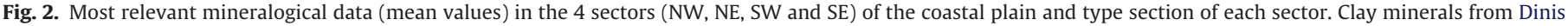

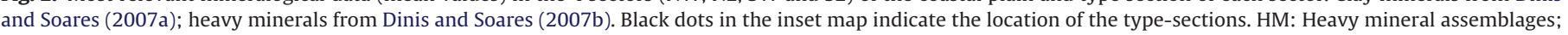

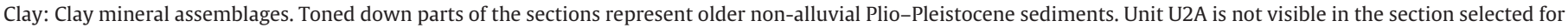
sector SE (the compositional data are from other sections).

an eastern, subsiding sector, at the contact with the Variscan Iberian massif, where the Plio-Pleistocene sedimentary record may reach $70 \mathrm{~m}$. This eastern sector has a complex structure determined by the intricate fault pattern, with several narrow horsts and grabens, usually elongated N-S. A north-south division may also be considered on the basis of the nature of rocks present to the east of the coastal margin and the continuity of the Plio-Pleistocene cover. In northern locations only occur the Precambrian of CIZ and the sediment cover is more continuous. In southern locations there are other basement units to the east of the coastal margin (OMZ, Silurian of $\mathrm{CIZ}$ and Carboniferous) and the sediment cover comprises smaller discontinuous patches.

\subsection{Plio-Pleistocene stratigraphy and facies}

The studied upper Neogene succession is part of a siliciclastic unit that extends throughout the Western Portuguese Margin with an overall trend of decreasing marine influence both up-section and east-wards (Cunha et al., 1993). The lower part of the succession (unit U1) consists mainly of fine-grained sands deposited in inner shelf to coastal environments. These sediments were dated to the Zanclean-Piacenzian transition (3.6-3.5 Ma) based on calcareous nannofossils (Biozone NN16; Cachão, 1989), marine molluscs and isotopic Sr dating of shells (Silva, 2001). The remaining succession (units U2A, U2B and U3) comprises mainly alluvial deposits (Fig. 2) and may be sub-divided into 3 facies grouping: dense alluvial flow, stream channel fill and floodplain-swamp-lake sediments (Table 1).

\subsubsection{Unit $U 2 A$}

Unit U2A ( $<15 \mathrm{~m})$ consists mainly of sand and gravel deposits that record the evolution from coastal to fluvial sedimentation. It is made up mainly of amalgamated couplets of gravel and sand beds that define normal graded channel-shaped accumulations; thin floodplain beds occur occasionally (Fig. 2). Quartz and quartzite are the most common gravel clasts. Andalusite, staurolite (common in eastern sectors), tourmaline, silimanite and zircon (common in the very fine sand fraction) are the most abundant translucent heavy minerals (Dinis and Soares, 2007b). The clay assemblages are dominated by kaolinite (Dinis and Soares, 2007a). Unit U2A was deposited in low sinuosity braided systems with high channel mobility under low accommodation conditions (Dinis, 2006).

\subsubsection{Unit $U 2 B$}

Unit U2B $(<50 \mathrm{~m})$ is characteristic of the more subsiding sectors of Certima Depression, where it evolves gradually from unit U2A. It is formed by floodplain and swamp-lake mud, sometimes articulated with peat-lignite, and both channelized and non-channelized alluvial sand-gravel beds. Unit U2B has significant proportion of slate-metagreywacke and angular white quartz gravel clasts, especially in the NE sector. The heavy assemblages are dominated by mica and staurolite (Dinis and Soares, 2007b) and the clay assemblages are dominated by illite (Dinis and Soares, 2007a). A north directed axial drainage, particularly in southern locations, is deduced from paleocurrent orientation and horizontal facies changes (Dinis, 2006). Higher accommodation conditions 
Table 1

Facies characteristics.

\begin{tabular}{|c|c|c|c|c|}
\hline Facies & Location & Lithology & Geometry and structure & Interpretation \\
\hline $\mathrm{A} 1$ & $\begin{array}{l}\text { Constitute the majority of unit } \\
\text { U3. Occasionally intercalated } \\
\text { with fine-grained deposits of } \\
\text { unit U2B. }\end{array}$ & $\begin{array}{l}\text { Pebble-boulder gravels with } \\
\text { sand-mud matrix. Clast- } \\
\text { supported or } \\
\text { matrix-supported. Presence of } \\
\text { rounded erosion resistant } \\
\text { clasts (quartz, quartzite and } \\
\text { silicified sandstones) in a } \\
\text { mixture with angular clasts. } \\
\text { Intercalated with sand-gravel } \\
\text { lenses. }\end{array}$ & $\begin{array}{l}\text { Massive or crudely stratified, } \\
\text { sometimes with imbrication. } \\
\text { Sharp-based, frequently } \\
\text { erosive, beds. Sand-gravel } \\
\text { lenses may show trough or } \\
\text { planar cross-stratification. Up } \\
\text { to } 3 \text { m thick beds. }\end{array}$ & $\begin{array}{l}\text { Clast to matrix-supported and } \\
\text { crude horizontal structure } \\
\text { suggest cohesionless debris } \\
\text { flow deposits. Intercalation of } \\
\text { cross-stratified lenses suggests } \\
\text { transition to water lain } \\
\text { transport. }\end{array}$ \\
\hline A2 & $\begin{array}{l}\text { In unit U2B, close to the } \\
\text { eastern edge of the basin. }\end{array}$ & $\begin{array}{l}\text { Matrix-supported gravels. } \\
\text { Clay-rich matrix. Erosion } \\
\text { resistant clasts usually very } \\
\text { angular. }\end{array}$ & $\begin{array}{l}\text { Massive or poorly organized. } \\
\text { Beds with sharp or transitional } \\
\text { contacts and limited lateral } \\
\text { extent. Up to } 1.5 \text { m thick. }\end{array}$ & $\begin{array}{l}\text { The clay richness and } \\
\text { matrix-supported texture, } \\
\text { frequency of very angular } \\
\text { clasts and the disorganized } \\
\text { fabric are indicative of } \\
\text { cohesive debris flows. }\end{array}$ \\
\hline B1 & $\begin{array}{l}\text { In unit U2B. Particularly in } \\
\text { southern and central locations. }\end{array}$ & $\begin{array}{l}\text { Clast-supported pebble or } \\
\text { granule gravels. Frequently } \\
\text { with mica rich fine-grained } \\
\text { matrix. }\end{array}$ & $\begin{array}{l}\text { Massive or imbricated } \\
\text { deposits. Occasionally with } \\
\text { cross-stratification. Concave } \\
\text { base deposits. Palaeocurrents } \\
\text { with low variability in outcrop. } \\
\text { Up to } 2 \mathrm{~m} \text { thick. }\end{array}$ & $\begin{array}{l}\text { Concave base geometry, gravel } \\
\text { size and homogeneous } \\
\text { palaeocurrents indicate } \\
\text { bed-load, low sinuosity, stream } \\
\text { deposits. }\end{array}$ \\
\hline B2 & $\begin{array}{l}\text { In unit U2B, particularly in } \\
\text { northern locations. }\end{array}$ & $\begin{array}{l}\text { Fine to very coarse sand } \\
\text { deposits. Frequent granules of } \\
\text { sub-rounded quartz or } \\
\text { quartzite. Mica rich matrix. } \\
\text { Intercalated with mud beds. }\end{array}$ & $\begin{array}{l}\text { Massive, graded, } \\
\text { cross-stratified or ripple } \\
\text { laminated. Erosive, concave } \\
\text { base beds. Channel orientation } \\
\text { and cross-stratification dip } \\
\text { with high variability in } \\
\text { outcrop. Up to } 1.5 \text { m thick. }\end{array}$ & $\begin{array}{l}\text { Channel geometry, sand } \\
\text { grain-size, variability in } \\
\text { palaeocurrent and } \\
\text { intercalation with thick mud } \\
\text { deposits suggest association } \\
\text { with sandy sinuous stream } \\
\text { channels. }\end{array}$ \\
\hline B3 & In the upper part of unit U2A. & $\begin{array}{l}\text { Couplets of gravel and sand } \\
\text { sediments. Domain of "hard" } \\
\text { (quartz, quartzite and silicified } \\
\text { sandstone) clasts. Frequent } \\
\text { well rounded granules and } \\
\text { pebbles. Intercalation of mud } \\
\text { beds rare or absent. }\end{array}$ & $\begin{array}{l}\text { Normal graded beds with } \\
\text { concave base. Usually with } \\
\text { cross-stratification. } \\
\text { Palaeocurrents with low } \\
\text { variability in outcrop. } 0.5-2 \mathrm{~m} \\
\text { thick. }\end{array}$ & $\begin{array}{l}\text { The amalgamated gravel-sand } \\
\text { sediments, absence of lateral } \\
\text { accretion surfaces, scarcity of } \\
\text { intercalated floodplain } \\
\text { deposits and low palaeocurrent } \\
\text { variability are indicative of } \\
\text { highly mobile channels in } \\
\text { braided systems. }\end{array}$ \\
\hline $\mathrm{C} 1$ & $\begin{array}{l}\text { Manly in unit U2B. Thicker in } \\
\text { fault limited areas of the SE } \\
\text { sector. }\end{array}$ & $\begin{array}{l}\text { Mud sediments of varied colors } \\
\text { (red, purple and grey). Deposits } \\
\text { contain a subsidiary fine sand } \\
\text { population. }\end{array}$ & $\begin{array}{l}\text { Horizontal lamination, } \\
\text { sometimes disrupted by metre } \\
\text { long, sub-vertical, macropeds. } \\
0.5-5 \text { m thick. }\end{array}$ & $\begin{array}{l}\text { Fine grain-size with limited } \\
\text { sand fraction, lamination and } \\
\text { presence of pedogenic features } \\
\text { point to vegetated floodplain. }\end{array}$ \\
\hline $\mathrm{C} 2$ & $\begin{array}{l}\text { In units U2A and U2B. Common } \\
\text { in the proximity of stream } \\
\text { deposits. }\end{array}$ & $\begin{array}{l}\text { Deposits consist of a mixture of } \\
\text { fine sand- coarse silt and fine } \\
\text { silt-clay populations. Usually } \\
\text { coarser in the proximity of } \\
\text { channel fill deposits. }\end{array}$ & $\begin{array}{l}\text { Ripple or parallel laminated } \\
\text { sandy mud. Tabular, lobe or } \\
\text { wedge-like metre thick bodies. } \\
<0.5 \text { m thick. }\end{array}$ & $\begin{array}{l}\text { Proximity to channel fill } \\
\text { deposits and coarser grain-size } \\
\text { than facies } C 1 \text { are indicative of } \\
\text { crevasse splay or levee } \\
\text { deposits. }\end{array}$ \\
\hline C3 & $\begin{array}{l}\text { In unit U2B. Associated with } \\
\text { facies C4. }\end{array}$ & $\begin{array}{l}\text { Grey mud with minor amounts } \\
\text { of sand to coarse silt particles. }\end{array}$ & $\begin{array}{l}\text { Massive or horizontally } \\
\text { laminated. Up to } 2 \mathrm{~m} \text { thick } \\
\text { lense shaped beds. Thicker in } \\
\text { subsiding sectors. }\end{array}$ & $\begin{array}{l}\text { Low proportion of sand and } \\
\text { coarse silt particles and the } \\
\text { associations with organic rich } \\
\text { sediments indicate settling of } \\
\text { fine grained sediments in a } \\
\text { shallow lake. }\end{array}$ \\
\hline $\mathrm{C} 4$ & $\begin{array}{l}\text { In unit U2B. Associated with } \\
\text { facies C3. }\end{array}$ & Lignite and peat. & $\begin{array}{l}\text { Up to } 2 \mathrm{~m} \text { thick lense shaped } \\
\text { beds. }\end{array}$ & $\begin{array}{l}\text { Lenticular organic facies } \\
\text { associated with lake sediments } \\
\text { indicate swamps environments } \\
\text { in the periphery of shallow } \\
\text { lakes. }\end{array}$ \\
\hline
\end{tabular}

are expected for the northern locations of the Certima Depression (Dinis, 2006).

The comparison of the palynological associations collected in unit U2B with those from the reference succession for the Portuguese Pliocene (Rio Maior succession, Diniz, 1984) suggests a Piacenzian (middle Pliocene) age (Vieira, 2009). This assumption is based on the presence of thermophilous elements (e.g. Taxodiaceae, Cathaya, Symplocos and Nyssa) which disappeared from Western Europe during the Gelasian (uppermost Pliocene) (Michaux et al., 1979; Suc and Zagwijn, 1983). The polinic record suggests a forest associated with a swamp/marsh environment developing under warm and humid climate (Vieira, 2009).

\subsubsection{Unit U3}

Unit U3 ( $<5 \mathrm{~m}$ thick) consists almost exclusively of coarse grained alluvial sediments that unconformably overlie the previous units, extending westward behind the limits of the Cértima Depression. The basal surface is frequently irregular and erosive, dipping to the west or northwest (up to $10^{\circ}$ ) and truncating sub-horizontal sediments of units U2A and U2B. The most common facies consists of sheet-like pebble to cobble gravel beds that usually contain well-rounded quartzite and quartz clasts in a mixture with finer angular elements. Silicified sandstones are common in southern locations. Unit U3 contains variable proportions of stable and ultrastable heavy minerals, with a higher proportion of staurolite in northern sites and tourmaline (frequently well rounded) in south- 


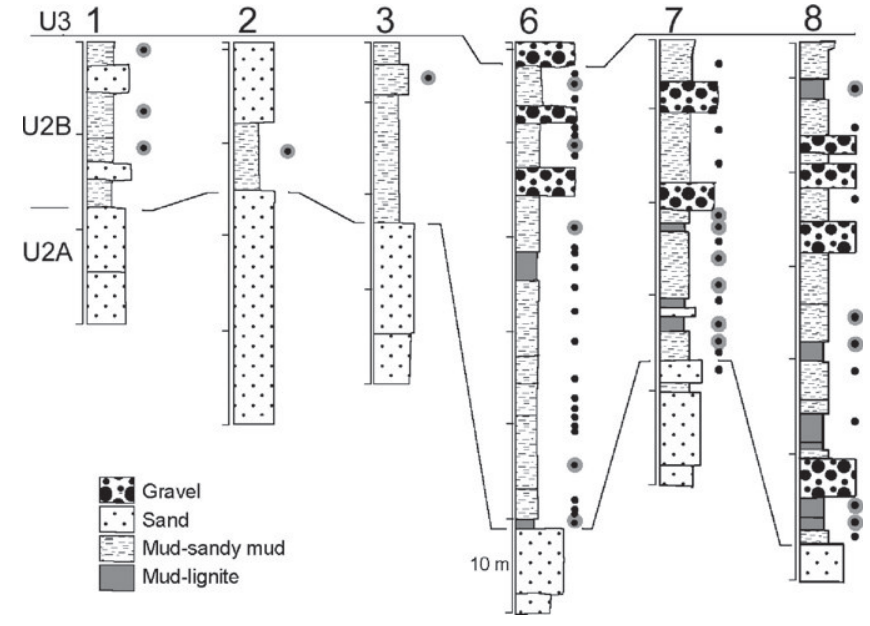

Fig. 3. Simplified borehole logs with position of samples selected for geochemical analysis. Small black dots represent samples analysed by XRF. Larger grey dots represent samples analysed by XRF and ICP-MS. Samples from locations 4 and 5 were collected in outcrops with partial exposure of the succession and are not represented here. Borehole locations in Fig. 1.

ern sites (Dinis and Soares, 2007b). The clay fraction composition is spatially variable (Dinis and Soares, 2007a). The unit is attributed to mainly sheetflood or non-cohesive debris-flow deposition (Dinis, 2006). Given the relationship of unit U3 with the commencement of fluvial incision, which is considered to be of early Pleistocene age (Cunha et al., 2008), it is tentatively attributed to the upper Pliocene or early Pleistocene.

\section{Methods}

A total of 60 sediments were collected in boreholes drilled along the Certima Depression ( 3 from the NE sector and 3 from the SE sector) and in selected outcrops (Figs. 1 and 3). Semi-quantitative clay mineralogy of $<2 \mu \mathrm{m}$ fraction and bulk sample was estimated by X-ray diffraction (XRD) from the peak areas of basal reflections weighted by empirical factors (Schultz, 1964; Thorez, 1976). Given the uncertainties involved in mineral quantification by XRD (see Kahle et al., 2002), the results obtained by this approach are viewed merely as rough estimates of actual mineral percentages. Main and trace elements were determined in Plio-Pleistocene sediments and basin edge Variscan rocks that may have constituted sediment sources (13 samples). Most elements were determined by X-Ray Fluorescence (XRF spectrometry). Homogenized powders of samples were previously digested with a mixture of $\mathrm{HF}, \mathrm{HNO}_{3}$ and $\mathrm{HClO}_{4}$. REE content was determined by Inductively Coupled Plasma Mass Spectrometry (ICP-MS) in Plio-Pleistocene sediments (27 selected samples) and the possible source rocks. Samples were mixed with $\mathrm{Na}_{2} \mathrm{O}_{2}$ and sintered at $480 \pm 10^{\circ} \mathrm{C}$ for $30 \mathrm{~min}$. After cooling, the REE were separated and concentrated with $\mathrm{HCl}$ and $\mathrm{HNO}_{3}$. The precision and accuracy of elemental determinations (XRF and ICP-MS) is better than $3 \%$ and $5 \%$, respectively, with the exception of $\mathrm{Lu}(6.6 \%$ and $11.9 \%$, respectively).

\section{Results}

\subsection{Pliocene-Pleistocene succession}

\subsubsection{Mineralogy}

XRD analysis of mud sediments indicate that quartz (25-73\%) is generally the most common mineral, surpassing illite (5-49\%) and kaolinite (12-37\%). Feldspar and iron oxides are present in limited proportions, but are higher in the coarser-grained floodplain facies. Feldspar is particularly common in lower stratigraphic levels.
The clay mineral assemblages are dominated by illite or kaolinite, while vermiculite, smectite and $10-14 \AA$ mixed layer clays occur in secondary proportions. Floodplain deposits have rather heterogeneous assemblages. Illite is usually more abundant than kaolinite, but higher proportions of kaolinite (up to 82\%) are found in the NE sector near the base of unit U2B. Illite is usually more abundant (30-87\%) in the swamp-shallow lake facies.

\subsubsection{Geochemistry}

The concentration of selected major and trace elements in mud sediments is presented in Table 2. Major elements concentrations in the studied sediments are compatible with the mineralogical data described above. Even though the XRD data are semi-quantitative, $\mathrm{SiO}_{2}$ correlates with quartz proportion and $\mathrm{Al}_{2} \mathrm{O}_{3}$ correlates with illite and kaolinite proportions (Fig. 4). The illite proportion shows correlation with $\mathrm{K}_{2} \mathrm{O}$ and $\mathrm{MgO}$ concentrations (Fig. 4). The correlation between illite and $\mathrm{MgO}$ suggests that $\mathrm{Mg}$ is partially integrated in the illite structure. Samples with more hematite also show higher Fe content. All sediments are depleted in $\mathrm{Na}_{2} \mathrm{O}$, which can be lower than the detection limit of the analytical methodology.

The different facies have comparable $\mathrm{SiO}_{2}$ (60-76\%), $\mathrm{Al}_{2} \mathrm{O}_{3}$ (15-23\%), $\mathrm{K}_{2} \mathrm{O}(2-3 \%)$ and $\mathrm{TiO}_{2}(0.7-1.2 \%)$. Swamp-lake sediments have slightly lower Fe content (mean of 2.7\%) than coarser grained floodplain sediments (mean of $4.1 \%$ ). Floodplain samples of sector $\mathrm{SE}$ tend to have lower $\mathrm{Al}_{2} \mathrm{O}_{3}$ and higher Fe concentrations (means of $18.5 \%$ and $4.6 \%$, respectively) than samples of the NE sector (means of $20.6 \%$ and $3.5 \%$, respectively); however, the variability in major elements is high, particularly in the NE sector.

Concerning trace elements, the concentration of $\mathrm{Y}$ is generally lower in the floodplain (7-23 ppm, mean of $13.4 \mathrm{ppm}$ ) than in swamp-lake facies (19-32 ppm, mean of $26.7 \mathrm{ppm}$ ). Among floodplain facies, sediments from the SE sector tend to be richer in Y than those from the NE sector. Th concentration is highly variable, but the mean values in floodplain and swamp-lake facies are comparable. REE concentrations are generally higher in the swamp-lake sediments (131-300 ppm, mean of $201.5 \mathrm{ppm}$ ) than in the floodplain sediments (62-218 ppm, mean of $134.2 \mathrm{ppm}$ ). The sum of heavy REE (HREE) concentrations is higher in swamp-lake sediments (12-15 ppm) than in floodplain (5-12 ppm). Floodplain sediments from the SE sector tend to be richer in HREE than floodplain sediments from the NE sector.

The pattern of distribution of REE is relatively homogeneous (Fig. 5A). The chondrite-normalized REE show slight enrichment in LREE, which tend to be more fractinated in the coarser sediments (mean $\mathrm{La}_{\mathrm{N}} / \mathrm{Yb}_{\mathrm{N}}$ ratios of 22.2 for facies $\mathrm{C} 2,9.8$ for facies $\mathrm{C} 1$ and 9.3 for facies C3). The patterns reveal flatter HREE $\left(\mathrm{Gd}_{N} / \mathrm{Yb}_{\mathrm{N}}\right.$ between 1.16 and 2.39), and more fractionated LREE $\left(\mathrm{La}_{\mathrm{N}} / \mathrm{Sm}_{\mathrm{N}}\right.$ between 2.18 and 5.97). A Eu negative anomaly is detected in all samples $\left(0.56<\mathrm{Eu} / \mathrm{Eu}^{*}<0.77\right)$. The anomaly is higher in lower sediments of unit U2B, at the transition to unit U2A. The Ce anomaly can be either slightly positive or negative $\left(0.74<\mathrm{Ce} / \mathrm{Ce}^{*}<1.21\right)$.

\subsection{Geochemistry of basin edge basement rocks}

Basement rocks from the basin border have variable concentrations of major elements (Table 3 ). $\mathrm{SiO}_{2}$ concentrations are lower in the Silurian rocks (49-51\%) than in the other formations (53-77\%). In opposition, $\mathrm{Al}_{2} \mathrm{O}_{3}$ is especially high in the Silurian (27-28\%) when compared to the other basin edge units (11-24\%). $\mathrm{K}_{2} \mathrm{O}, \mathrm{Na}_{2} \mathrm{O}$ and $\mathrm{CaO}$ concentrations are relatively low.

The concentrations of Th (4-13 ppm) and REE (63-201 ppm) are variable within the basin edge rocks, though they tend to be higher in the finer grained samples of OMZ and Silurian and lower in coarser grained Carboniferous and Precambrian of CIZ. The REE patterns are comparable (Fig. 5B). The chondrite-normalized patterns reveal slight LREE enrichment $\left(\mathrm{La}_{\mathrm{N}} / \mathrm{Yb}_{\mathrm{N}}\right.$ between 5.68 and 
Table 2

Selected geochemical data for floodplain (facies $\mathrm{C} 1$ and C2) and swamp-lake sediments (facies C3).

\begin{tabular}{|c|c|c|c|c|c|c|c|c|c|c|c|c|c|c|c|c|c|c|c|c|c|c|c|}
\hline Sample & Facies & $\begin{array}{l}\mathrm{SiO}_{2} \\
\text { (wt\%) }\end{array}$ & $\begin{array}{l}\mathrm{Al}_{2} \mathrm{O}_{3} \\
\text { (wt\%) }\end{array}$ & $\begin{array}{l}\mathrm{Fe}_{\text {tot }} \\
\text { (wt\%) }\end{array}$ & $\begin{array}{l}\mathrm{CaO} \\
(\mathrm{wt} \%)\end{array}$ & $\begin{array}{l}\mathrm{K}_{2} \mathrm{O} \\
(\mathrm{wt} \%)\end{array}$ & $\begin{array}{l}\mathrm{Y} \\
(\mathrm{ppm})\end{array}$ & $\begin{array}{l}\text { Th } \\
(\mathrm{ppm})\end{array}$ & $\begin{array}{l}\text { La } \\
(\mathrm{ppm})\end{array}$ & $\begin{array}{l}\mathrm{Ce} \\
(\mathrm{ppm})\end{array}$ & $\begin{array}{l}\operatorname{Pr} \\
(\mathrm{ppm})\end{array}$ & $\begin{array}{l}\mathrm{Nd} \\
(\mathrm{ppm})\end{array}$ & $\begin{array}{l}\text { Sm } \\
(\mathrm{ppm})\end{array}$ & $\begin{array}{l}\mathrm{Eu} \\
(\mathrm{ppm})\end{array}$ & $\begin{array}{l}\text { Gd } \\
(\mathrm{ppm})\end{array}$ & $\begin{array}{l}\mathrm{Tb} \\
(\mathrm{ppm})\end{array}$ & $\begin{array}{l}\text { Dy } \\
\text { (ppm) }\end{array}$ & $\begin{array}{l}\text { Ho } \\
(\mathrm{ppm})\end{array}$ & $\begin{array}{l}\mathrm{Er} \\
(\mathrm{ppm})\end{array}$ & $\begin{array}{l}\text { Tm } \\
(\mathrm{ppm})\end{array}$ & $\begin{array}{l}\mathrm{Yb} \\
(\mathrm{ppm})\end{array}$ & $\begin{array}{l}\mathrm{Lu} \\
(\mathrm{ppm})\end{array}$ & CIA \\
\hline $1-3$ & $\mathrm{C} 1$ & 60.13 & 21.85 & 5.49 & 0.04 & 2.29 & 14.91 & 16.33 & 32.66 & 71.51 & 7.84 & 26.89 & 4.37 & 0.98 & 3.36 & 0.51 & 2.98 & 0.57 & 1.67 & 0.25 & 1.70 & 0.27 & 89 \\
\hline $1-2$ & $\mathrm{C} 1$ & 61.35 & 23.24 & 3.27 & 0.05 & 3.01 & 15.57 & 15.21 & 41.13 & 104.24 & 10.57 & 39.22 & 7.29 & 1.37 & 5.23 & 0.72 & 3.65 & 0.64 & 1.76 & 0.26 & 1.77 & 0.28 & 87 \\
\hline $1-1$ & $\mathrm{C} 1$ & 61.82 & 21.66 & 3.94 & 0.07 & 2.18 & 8.40 & 10.42 & 14.24 & 25.52 & 4.30 & 15.04 & 3.19 & 0.54 & 2.50 & 0.37 & 2.05 & 0.38 & 1.08 & 0.17 & 1.23 & 0.20 & 90 \\
\hline $2-1$ & $\mathrm{C} 1$ & 60.65 & 22.19 & 4.90 & 0.08 & 2.53 & 6.66 & 8.57 & 23.04 & 53.01 & 7.57 & 26.23 & 5.28 & 0.84 & 3.69 & 0.50 & 2.54 & 0.45 & 1.17 & 0.17 & 1.25 & 0.21 & 88 \\
\hline $4-2$ & $\mathrm{C} 1$ & 64.27 & 21.94 & 1.28 & 0.07 & 2.95 & 13.66 & 10.68 & 23.63 & 55.77 & 7.82 & 33.01 & 6.82 & 1.32 & 4.43 & 0.55 & 2.80 & 0.53 & 1.54 & 0.24 & 1.86 & 0.29 & 88 \\
\hline 4-1 & $\mathrm{C} 1$ & 76.10 & 14.80 & 0.72 & 0.06 & 2.27 & 8.77 & 6.74 & 20.03 & 45.03 & 6.10 & 24.44 & 4.29 & 0.79 & 2.42 & 0.28 & 1.52 & 0.31 & 0.98 & 0.16 & 1.26 & 0.19 & 86 \\
\hline 5-3 & $\mathrm{C} 1$ & 64.90 & 18.20 & 5.91 & 0.04 & 3.27 & 11.62 & 10.34 & 26.22 & 51.54 & 7.13 & 28.34 & 5.05 & 0.95 & 3.01 & 0.36 & 2.02 & 0.40 & 1.26 & 0.21 & 1.64 & 0.25 & 85 \\
\hline $5-2$ & $\mathrm{C} 1$ & 66.08 & 21.14 & 2.11 & 0.03 & 3.17 & 9.00 & 8.82 & 24.52 & 51.98 & 7.22 & 27.15 & 4.67 & 0.86 & 2.59 & 0.30 & 1.67 & 0.33 & 1.11 & 0.18 & 1.50 & 0.25 & 87 \\
\hline 5-1 & $\mathrm{C} 1$ & 64.72 & 20.27 & 3.59 & 0.02 & 2.86 & 8.76 & 5.09 & 20.35 & 44.11 & 7.19 & 25.58 & 5.01 & 0.92 & 3.51 & 0.50 & 2.86 & 0.58 & 1.69 & 0.27 & 1.95 & 0.33 & 88 \\
\hline $6-24$ & $\mathrm{C} 1$ & 64.26 & 17.60 & 7.04 & 0.04 & 2.68 & 10.01 & 8.57 & 19.70 & 39.88 & 5.04 & 18.84 & 3.34 & 0.63 & 2.04 & 0.26 & 1.61 & 0.34 & 1.10 & 0.18 & 1.41 & 0.21 & 87 \\
\hline $6-20$ & $\mathrm{C} 1$ & 65.50 & 18.90 & 4.59 & 0.04 & 2.87 & 16.03 & 9.53 & 31.95 & 58.32 & 9.01 & 37.24 & 6.65 & 1.26 & 4.12 & 0.50 & 2.71 & 0.53 & 1.61 & 0.25 & 1.94 & 0.30 & 87 \\
\hline 6-17 & $\mathrm{C} 1$ & 62.49 & 20.87 & 3.91 & 0.05 & 2.46 & 22.50 & 9.72 & 37.28 & 83.86 & 10.06 & 35.68 & 7.56 & 1.44 & 5.31 & 0.72 & 4.15 & 0.80 & 2.42 & 0.36 & 2.66 & 0.42 & 89 \\
\hline 6-5 & $\mathrm{C} 1$ & 65.90 & 18.60 & 4.53 & 0.06 & 2.94 & 16.12 & 7.61 & 25.00 & 57.13 & 6.81 & 23.23 & 4.63 & 0.91 & 3.72 & 0.57 & 3.47 & 0.71 & 2.14 & 0.33 & 2.34 & 0.37 & 86 \\
\hline 8-7 & $\mathrm{C} 1$ & 71.20 & 15.46 & 4.49 & 0.04 & 2.59 & 14.45 & 10.18 & 33.39 & 78.41 & 8.84 & 34.43 & 6.41 & 1.43 & 4.64 & 0.61 & 3.44 & 0.68 & 2.06 & 0.33 & 2.21 & 0.36 & 85 \\
\hline 8-5 & $\mathrm{C} 1$ & 62.72 & 22.21 & 3.02 & 0.06 & 2.93 & 18.76 & 7.82 & 22.81 & 49.53 & 5.20 & 19.84 & 3.68 & 0.92 & 3.54 & 0.59 & 3.88 & 0.81 & 2.45 & 0.38 & 2.47 & 0.40 & 88 \\
\hline 7-9 & $\mathrm{C} 1$ & 63.55 & 17.77 & 7.42 & 0.04 & 2.83 & 17.83 & 8.74 & 31.30 & 54.01 & 7.05 & 23.51 & 4.72 & 0.87 & 3.35 & 0.47 & 2.74 & 0.56 & 1.71 & 0.27 & 2.08 & 0.33 & 86 \\
\hline 7-7 & $\mathrm{C} 1$ & 69.06 & 16.56 & 4.07 & 0.05 & 2.89 & 16.16 & 10.17 & 32.92 & 74.09 & 9.08 & 31.38 & 5.97 & 1.12 & 4.24 & 0.59 & 3.46 & 0.70 & 2.11 & 0.33 & 2.35 & 0.37 & 84 \\
\hline 7-6 & $\mathrm{C} 1$ & 67.33 & 19.17 & 1.79 & 0.06 & 3.23 & 7.30 & 3.53 & 12.96 & 24.74 & 3.40 & 12.29 & 2.52 & 0.44 & 1.73 & 0.26 & 1.49 & 0.31 & 0.94 & 0.14 & 1.15 & 0.19 & 84 \\
\hline 7-3 & $\mathrm{C} 1$ & 64.97 & 18.41 & 5.16 & 0.11 & 2.85 & 21.88 & 9.18 & 30.46 & 57.88 & 8.45 & 29.20 & 5.95 & 1.18 & 4.87 & 0.73 & 4.32 & 0.88 & 2.58 & 0.39 & 2.66 & 0.43 & 86 \\
\hline 3-1 & $\mathrm{C} 2$ & 65.03 & 19.26 & 4.56 & 0.02 & 1.79 & 10.07 & 14.10 & 31.53 & 46.96 & 6.47 & 18.99 & 3.33 & 0.56 & 2.25 & 0.33 & 1.78 & 0.33 & 0.90 & 0.12 & 0.96 & 0.15 & 90 \\
\hline 6-1 & C3 & 62.43 & 21.61 & 1.87 & 0.10 & 3.29 & 26.45 & 15.55 & 41.17 & 109.60 & 10.97 & 37.77 & 8.15 & 1.46 & 6.26 & 0.88 & 4.92 & 0.89 & 2.48 & 0.36 & 2.45 & 0.36 & 83 \\
\hline $7-8$ & C3 & 60.68 & 22.88 & 3.35 & 0.06 & 3.32 & 26.92 & 9.04 & 38.25 & 98.37 & 9.40 & 31.77 & 6.43 & 1.24 & 5.10 & 0.75 & 4.51 & 0.90 & 2.71 & 0.41 & 2.92 & 0.45 & 86 \\
\hline $7-4$ & C3 & 65.13 & 20.77 & 0.99 & 0.15 & 3.33 & 29.02 & 9.89 & 38.25 & 75.62 & 8.87 & 30.26 & 5.81 & 1.14 & 5.10 & 0.77 & 4.79 & 0.96 & 2.83 & 0.42 & 2.92 & 0.45 & 86 \\
\hline $8-10$ & C3 & 64.34 & 21.00 & 2.08 & 0.04 & 2.76 & 26.49 & 10.59 & 57.36 & 130.27 & 15.32 & 60.21 & 10.95 & 2.45 & 8.03 & 1.06 & 5.63 & 1.09 & 3.16 & 0.48 & 3.14 & 0.51 & 88 \\
\hline $8-6$ & C3 & 64.02 & 20.32 & 4.20 & 0.04 & 3.28 & 27.20 & 10.07 & 38.26 & 99.03 & 9.24 & 31.26 & 6.12 & 1.15 & 4.93 & 0.72 & 4.35 & 0.87 & 2.58 & 0.38 & 2.76 & 0.43 & 86 \\
\hline $8-3$ & C3 & 66.52 & 20.05 & 1.89 & 0.08 & 3.30 & 19.31 & 8.44 & 27.26 & 49.55 & 7.32 & 25.09 & 4.89 & 0.99 & 4.23 & 0.66 & 4.14 & 0.84 & 2.51 & 0.38 & 2.62 & 0.41 & 86 \\
\hline $8-2$ & C3 & 68.88 & 16.36 & 4.47 & 0.08 & 2.71 & 31.5 & 10.1 & 31 & 69 & 8.4 & 32.9 & 6.1 & 1.5 & 6.0 & 0.9 & 5.4 & 1.1 & 3.2 & 0.5 & 2.9 & 0.5 & 85 \\
\hline
\end{tabular}

The first number of sample reference indicates section; the second number indicates the position (starting from the bottom) in the section. 

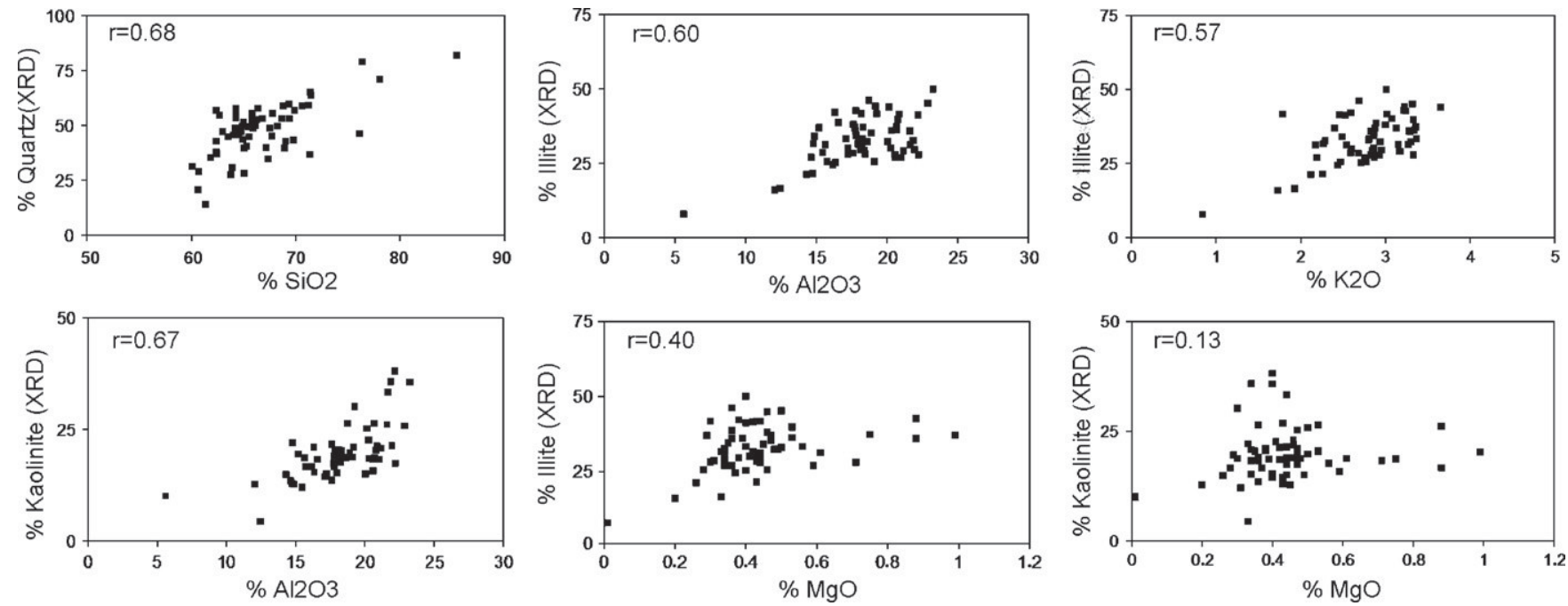

Fig. 4. Relation between the proportions of the most common minerals, as determined by XRD, and the concentration of main elements. Correlations higher than 0.20 are significant for $95 \%$ probability.

13.94), with more fractionated LREE $\left(\mathrm{La}_{\mathrm{N}} / \mathrm{Sm}_{\mathrm{N}}\right.$ between 2.50 and 4.08) than HREE $\left(\mathrm{Gd}_{\mathrm{N}} / \mathrm{Yb}_{\mathrm{N}}\right.$ between 1.44 and 2.10), and strong negative Eu anomaly (Eu/Eu* between 0.60 and 0.83 ). CIZ Precambrian rocks have lower Eu/Eu* anomaly (0.77-0.83) than the other Variscan formations $(0.60-0.71)$. The Ce anomaly is negligible $\left(0.86<\mathrm{Ce} / \mathrm{Ce}^{*}<1.11\right)$.
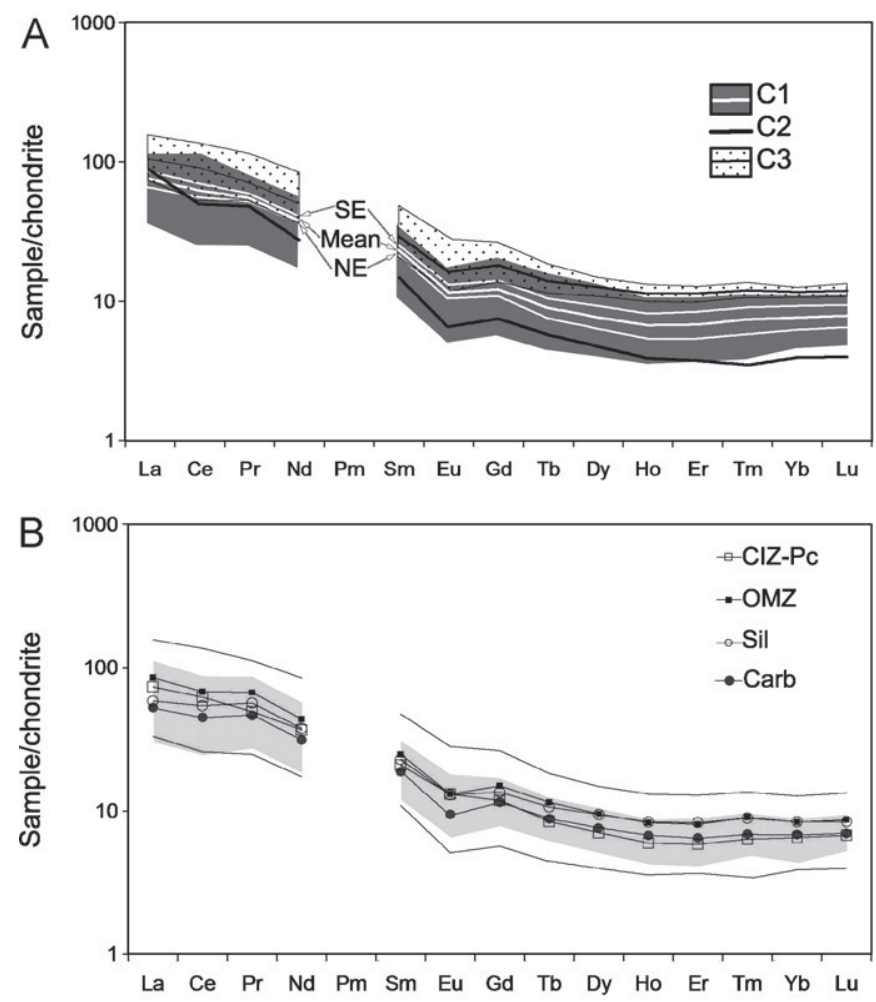

Fig. 5. Chondrite-normalized REE patterns. (A) REE patterns of different mud facies of unit U2B. For facies $\mathrm{C} 1$ and $\mathrm{C} 3$ both the range and mean values are represented. $\mathrm{SE}$ and NE indicate facies $\mathrm{C} 1$ mean values in these two sectors for. (B) Comparison between the range of chondrite-normalized REE patterns of mud facies (maximum and minimum values marked by black lines), possible source units (shaded zone) and their mean values. CIZ-Pc: Precambrian from the Central Iberian Zone; OMZ: Ossa Morena Zone; Sil: Silurian; Carb: Carboniferous.

\section{Discussion}

\subsection{Controls on sediment composition}

The analysis of the correlations of REE with other elements and mineral proportions helps to understand which mineral phases host REE (Table 4). Zircon and Ti-minerals (ilmenite and rutile) were found in the heavy fraction (Dinis and Soares, 2007b), but $\mathrm{Zr}$ and $\mathrm{TiO}_{2}$ do not correlate with REE, indicating that these minerals must have minor contribution to the REE geochemistry. The lesser concentrations of REE in the coarser-grained facies must be attributed to dilution by quartz, while the higher concentrations in the finer-grained facies and the significant correlations of illite with REE and LREE in floodplain facies of NE sector suggest that part of the REE is retained in this clay mineral. This hypothesis is supported by the tendency for LREE enrichment in illite (Cullers et al., 1975; Taylor and McLennan, 1985; Condie et al., 1995). However, due to the absence of correlation REE- $\mathrm{K}_{2} \mathrm{O}$, and REE-illite in the other facies and sectors, the majority of the REE must be present in different mineral phases.

REE and LREE in floodplain facies strongly correlate with Th (except for the NE sector) and Y, indicating that an important proportion of the REE must occur in monazite and xenotime. Because HREE correlates better with $Y$ than with Th one can assume that the HREE incorporation in monazite is less important than in Y-bearing minerals. Regarding swamp-lake facies, the absence of correlation REE-Y and REE-Th and the negative correlation HREE- $\mathrm{K}_{2} \mathrm{O}$ indicate that other phases must be involved in REE geochemistry. Because REE can be adsorbed in organic matter (Gotze and Lewis, 1994; Aubert et al., 2004; Xu and Han, 2009) and these sediments (facies C3) are articulated with lignite beds (facies C4), it may be considered that an important part of the REE is hosted by organic compounds. Organic matter adsorption also justifies the higher HREE concentration in facies C3, as organic matter tends to be richer in these elements (Aubert et al., 2004).

When LREE and HREE fractionations are plotted together (as proposed by Roy and Smykatz-Klos, 2007), most Plio-Pleistocene sediments and the younger basin edge formations (Silurian and Carboniferous) tend to show either less $(\mathrm{Gd} / \mathrm{Yb})_{\mathrm{N}}$ or $(\mathrm{La} / \mathrm{Sm})_{\mathrm{N}}$ ratios than the older basement rocks (Fig. 6). The only sediments that have higher ratios than the range of variation of the basement rocks are a few coarse floodplain facies that are intervened with channel fill facies at the transition U2A-U2B in the NE sector. Given the cor- 

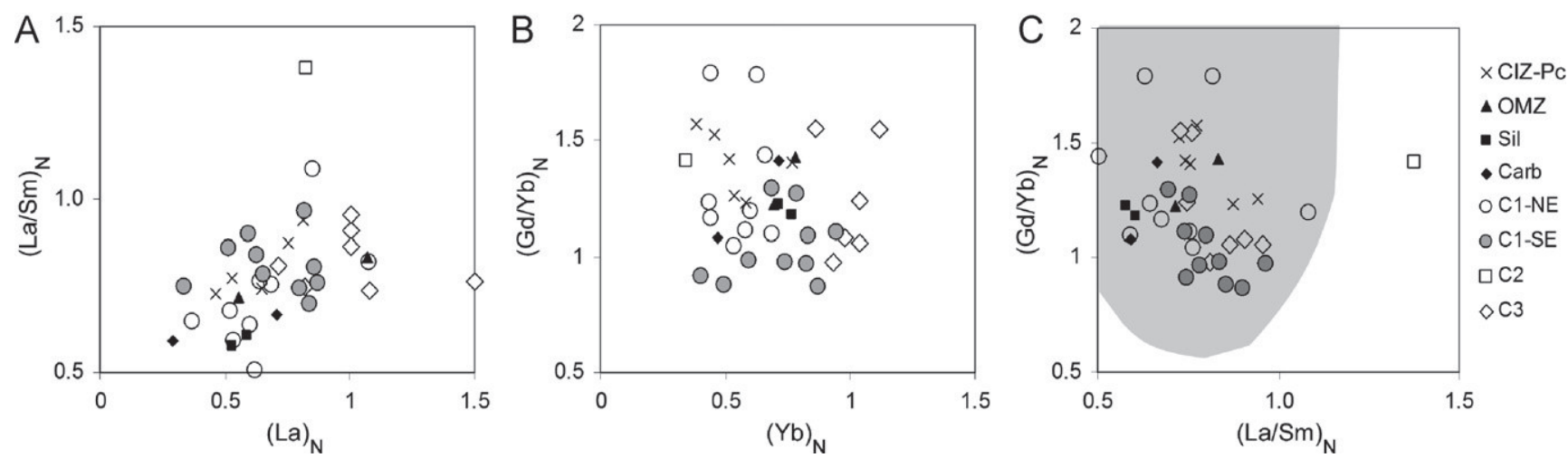

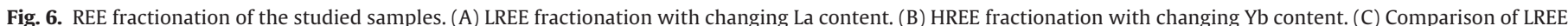

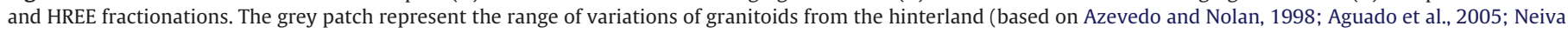
et al., 2009). Concentration normalized to Post-Archean Australian Shale. CIZ-Pc: Precambrian from the Central Iberian Zone; OMZ: Ossa Morena Zone; Sil: Silurian; Carb: Carboniferous.

relations between these REE ratios and Th and illite (Table 4), the decrease in the REE ratios may be related to weathering of these. Regarding monazite, which host significant proportions of REE, it has been argued that their REE are released through weathering and tend to precipitate with immobile secondary phosphates like xenotime (Jonasson et al., 1988; Braun et al., 1993).

Studies of weathering transformation and palaeoclimatic conditions frequently consider the chemical index of alteration ( $\mathrm{CIA}=100 \times \mathrm{Al}_{2} \mathrm{O}_{3} /\left(\mathrm{Al}_{2} \mathrm{O}_{3}+\mathrm{CaO}^{*}+\mathrm{Na}_{2} \mathrm{O}+\mathrm{K}_{2} \mathrm{O}\right)$ ) proposed by Nesbitt and Young (1982). To calculate CIA in the samples with $\mathrm{Na}_{2} \mathrm{O}$ below detection level $(0.02 \%)$ it was considered that it was absent. The very high values of CIA in Plio-Pleistocene sediments (>83, Table 2 ) suggest intense weathering in the source area. This assumption is also supported by the relatively high REE content in the studied samples, since these elements tend to be immobile during weathering and thereby concentrate in the sedimentary deposits (Taylor and McLennan, 1985; López et al., 2005). However, the high CIA may also be explained by the inheritance of features of earlier cycle rocks. In fact, the metasedimentary units from the basin edge already exhibit high values of CIA and REE concentrations (Table 3). The correlations REE-CIA and LREE-CIA in swamp-lake facies indicate some REE enrichment in "mature", Al-rich, sediments.

The resemblances between the REE geochemistry of the Plio-Pleistocene sediments and basin edge rocks suggest relatively low transformations through exogenous processes. This is more likely under tectonically active conditions, when source area gradients are higher, limiting the extent of weathering and favouring erosion (Chamley, 1989; Tripathi et al., 2007). There are several indicators of an important tectonic control over sedimentation in the studied succession, namely: (1) distinctive thickness and facies in subsiding and uplifted sectors, particularly in unit U2B (Fig. 2); (2) The frequent signs of syn-sedimentary deformation in units U2A and U2B, particularly in the proximity to major faults; (3) The palaeocurrent pattern, indicating that streams from the east were deflected northward against intrabasinal horsts (Dinis, 2006).

\subsection{Evolution in sediment provenance}

The evidence that $\mathrm{Mg}$ is integrated in the structure of illites of unit U2B (Fig. 4), as Mg rich illites are considered characteristic of unweathered materials (Gingele, 1996), point to a detrital origin. This possibility was already presented on the basis of illite crystallinity (Dinis and Soares, 2007a). The clay assemblages with abundant detrital illite, coupled with the frequency of slate and metagreywacke in the gravel fraction and mica in the heavy mineral fraction, indicate that unit U2B was primarily derived from the pelitic rocks of the uplifted Variscan Iberian Massif. The REE concentrations and patterns (Fig. 5) also indicate that unit U2B must have been mainly sourced from the metapelitic formations. LREE concentrations reflect inheritance and enrichment from the mica-rich rocks of the basin edge. The more variable HREE content is probably related to retention in organic compounds in swamp-lake facies and quartz dilution in coarser floodplain sediments.

When plotted in the $\mathrm{Al}_{2} \mathrm{O}_{3}-\mathrm{CAO}^{*}+\mathrm{Na}_{2} \mathrm{O}-\mathrm{K}_{2} \mathrm{O}$ diagram, Plio-Pleistocene samples are scattered in a region between idealized illite and kaolinite compositions, frequently with higher $\mathrm{Al}_{2} \mathrm{O}_{3}$ content than basin edge basement rocks (Fig. 7). Only the Silurian samples, which outcrop in southern parts of the study area, have higher $\mathrm{Al}_{2} \mathrm{O}_{3}$ content than the Plio-Pleistocene sediments. This suggests that, although unit U2B involved a north directed axial drainage, the alluvial system had mainly lateral sediment supply from eastern uplifted sectors, with limited contribution of the Silurian rocks.

Significant contribution of different sediment sources is deduced for the older and younger alluvial sediments. The high proportions of kaolinite, ultrastable heavy minerals and feldspar in sand-gravel sediments of unit U2A is attributed to hinterland provenance. The higher $(\mathrm{Gd} / \mathrm{Yb})_{\mathrm{N}}$ or $(\mathrm{La} / \mathrm{Sm})_{\mathrm{N}}$ ratios than the range of variation of basin edge rocks in older and coarser floodplain sediments (transition U2A-U2B) from NE sector may be explained

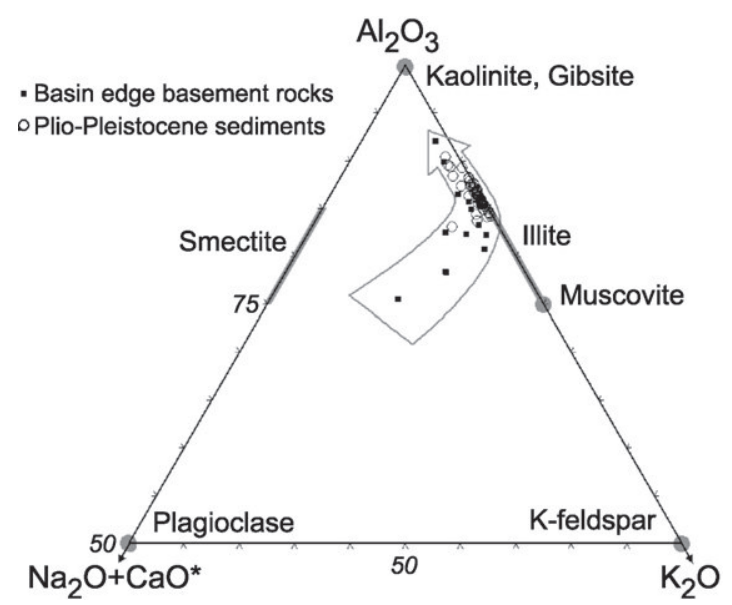

Fig. 7. Ternary plot (more than $50 \% \mathrm{Al}_{2} \mathrm{O}_{3}$ ) of molecular proportions $\mathrm{Al}_{2} \mathrm{O}_{3}-\left(\mathrm{Na}_{2} \mathrm{O}+\mathrm{CaO}^{*}\right)-\mathrm{K}_{2} \mathrm{O}$ for the Plio-Pleistocene alluvial sediments and basin edge basement rocks. The arrow represents the expected chemical evolution due to progressive weathering. The two possible source rock samples with highest $\mathrm{Al}_{2} \mathrm{O}_{3}$ content are from Silurian metapelitic units. 


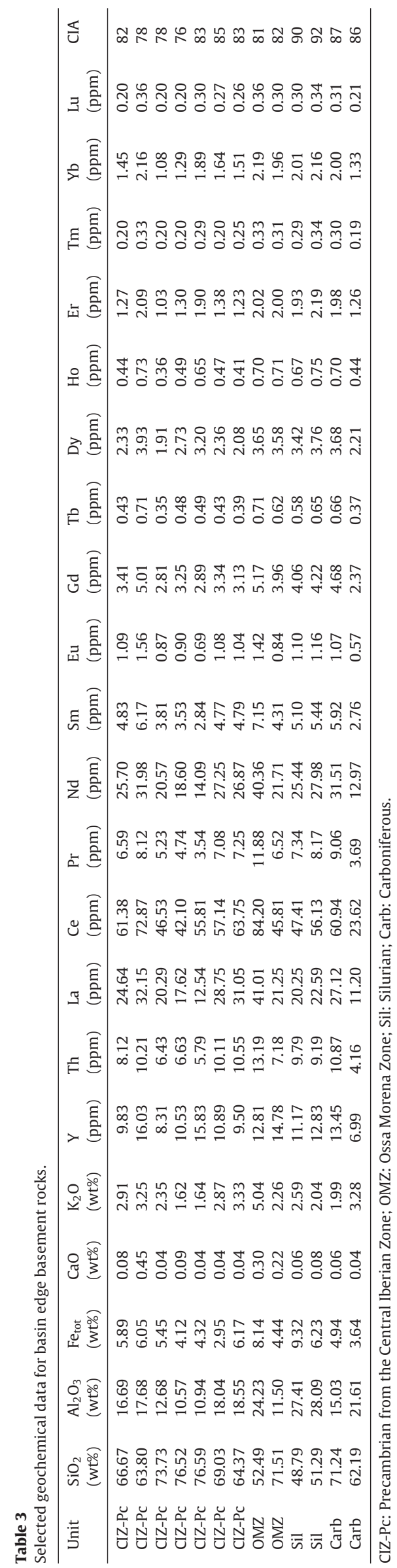

Table 4

Correlation coefficient between REE and REE ratios and some other elements, CIA and illite in the different facies and sectors.

\begin{tabular}{|c|c|c|c|c|c|c|}
\hline & & $\mathrm{K}_{2} \mathrm{O}$ & CIA & Th & $\mathrm{Y}$ & Illite \\
\hline Total & $\begin{array}{l}\text { REE } \\
\text { LREE } \\
\text { HREE } \\
(\mathrm{La} / \mathrm{Sm})_{\mathrm{N}} \\
(\mathrm{Gd} / \mathrm{Yb})_{\mathrm{N}}\end{array}$ & 0.39 & & \begin{tabular}{l|}
$\mathbf{0 . 4 9}$ \\
$\mathbf{0 . 5 1}$ \\
\\
0.41 \\
0.56
\end{tabular} & $\begin{array}{l}0.73 \\
0.70 \\
0.93\end{array}$ & \\
\hline $\begin{array}{l}\text { Facies C1 } \\
\text { Total }\end{array}$ & $\begin{array}{l}\text { REE } \\
\text { LREE } \\
\text { HREE } \\
(\mathrm{La} / \mathrm{Sm})_{\mathrm{N}} \\
(\mathrm{Gd} / \mathrm{Yb})_{\mathrm{N}}\end{array}$ & & & $\begin{array}{l}0.72 \\
0.73 \\
\\
0.55\end{array}$ & $\begin{array}{l}0.74 \\
0.71 \\
0.90\end{array}$ & 0.49 \\
\hline $\begin{array}{l}\text { Facies C1 } \\
\text { Sector NE }\end{array}$ & $\begin{array}{l}\text { REE } \\
\text { LREE } \\
\text { HREE } \\
(\mathrm{La} / \mathrm{Sm})_{\mathrm{N}} \\
(\mathrm{Gd} / \mathrm{Yb})_{\mathrm{N}}\end{array}$ & & & 0.72 & $\begin{array}{l}0.78 \\
0.77 \\
0.70\end{array}$ & $\begin{array}{l}0.72 \\
0.72 \\
\\
0.88\end{array}$ \\
\hline $\begin{array}{l}\text { Facies C1 } \\
\text { Sector SE }\end{array}$ & $\begin{array}{l}\text { REE } \\
\text { LREE } \\
\text { HREE } \\
(\mathrm{La} / \mathrm{Sm})_{\mathrm{N}} \\
(\mathrm{Gd} / \mathrm{Yb})_{\mathrm{N}}\end{array}$ & & & $\begin{array}{l}\mathbf{0 . 9 0} \\
\mathbf{0 . 9 1} \\
0.65 \\
\\
\mathbf{0 . 8 0}\end{array}$ & $\begin{array}{l}0.81 \\
0.79 \\
0.91\end{array}$ & \\
\hline $\begin{array}{l}\text { Facies C3 } \\
\text { Total }\end{array}$ & $\begin{array}{l}\text { REE } \\
\text { LREE } \\
\text { HREE } \\
(\mathrm{La} / \mathrm{Sm})_{\mathrm{N}} \\
(\mathrm{Gd} / \mathrm{Yb})_{\mathrm{N}}\end{array}$ & $\begin{array}{r}0.82 \\
-0.84\end{array}$ & $\begin{array}{l}0.91 \\
0.91\end{array}$ & 0.82 & & \\
\hline $\begin{array}{l}\text { Sector SE } \\
\text { Total }\end{array}$ & $\begin{array}{l}\text { REE } \\
\text { LREE } \\
\text { HREE } \\
(\mathrm{La} / \mathrm{Sm})_{\mathrm{N}} \\
(\mathrm{Gd} / \mathrm{Yb})_{\mathrm{N}}\end{array}$ & & & $\begin{array}{l}\mathbf{0 . 7 2} \\
\mathbf{0 . 7 2} \\
0.56 \\
\\
\mathbf{0 . 7 3}\end{array}$ & $\begin{array}{l}0.72 \\
0.69 \\
0.92\end{array}$ & \\
\hline $\begin{array}{l}\text { Sector NE } \\
\text { Total }\end{array}$ & $\begin{array}{l}\text { REE } \\
\text { LREE } \\
\text { HREE } \\
(\mathrm{La} / \mathrm{Sm})_{\mathrm{N}} \\
(\mathrm{Gd} / \mathrm{Yb})_{\mathrm{N}}\end{array}$ & & & 0.68 & $\begin{array}{l}\mathbf{0 . 7 8} \\
0.77\end{array}$ & 0.65 \\
\hline
\end{tabular}

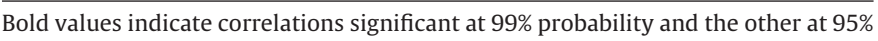
probability.

by external (i.e. from hinterland) provenance. This provenance would also explain the distinct Eu/Eu* anomaly in these sediments (0.56-0.59). In fact, the Eu anomaly in igneous rocks from central Portugal (Azevedo and Nolan, 1998; Aguado et al., 2005; Neiva et al., 2009 ) is highly variable (0.19-0.76), but can be substantially higher than in basin edge units (0.60-0.83). Meanwhile, the REE patterns $\left(\mathrm{Eu} / \mathrm{Eu}^{*}, \mathrm{La} / \mathrm{Sm}\right.$ and $\left.\mathrm{Gd} / \mathrm{Yb}\right)$ suggest that even the older sediments of unit U2B at the SE sectors were largely derived from basin-edge rocks.

Recycling of previous sediments explains the mixture of rounded mechanically resistant and non-abraded elements in unit U3. The possibility of a progressive increase in the proportion of recycled sediments through unit $\mathrm{U} 2 \mathrm{~B}$ is also supported by the high CIA in the upper part of the succession (Fig. 8), as the expected climate evolution (from middle Pliocene to lower Pleistocene) would not favour an increase in weathering intensity. Furthermore, because recycling processes would promote an increase in $\mathrm{SiO}_{2} / \mathrm{TiO}_{2}$ (Gu et al., 2002; Corcoran, 2005), the frequently high values of this ratio at the top of the succession reinforce the hypothesis of recycling processes. However, as Ti is expected to be released through weathering of unstable minerals but rapidly precipitated before being transported out of the area of weathering (Nesbitt and Markovics, 1997) and concentrated in fine grained sediments (Singh, 2009), this relation depends on sediment grain-size. Hence, some $\mathrm{SiO}_{2} / \mathrm{TiO}_{2}$ excursions are probably associated with grain-size variations. The XRD determined clay mineralogy do not follow any 

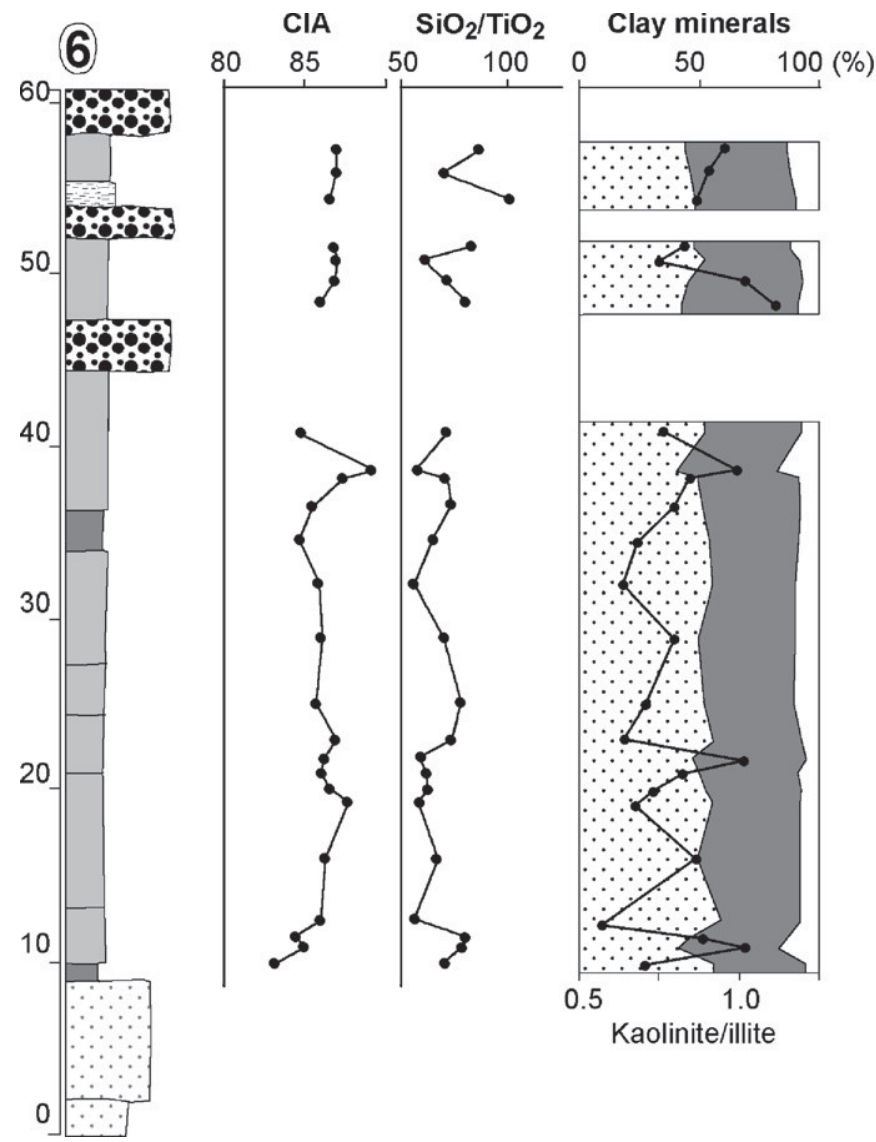
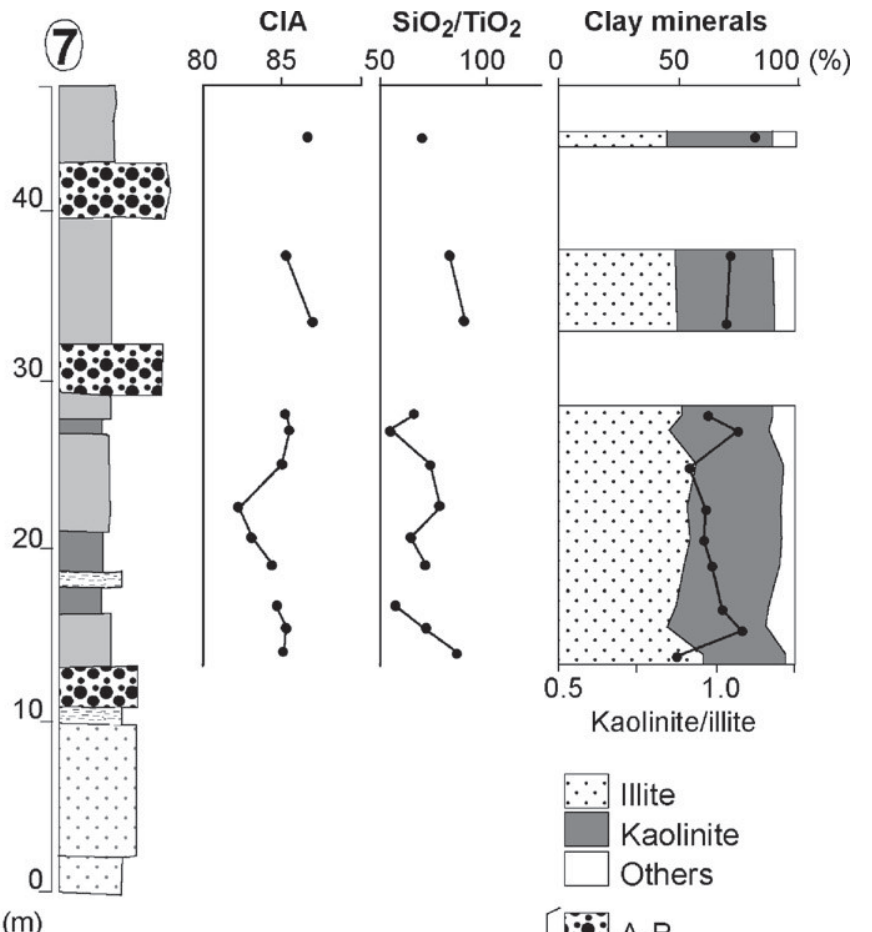

(m)

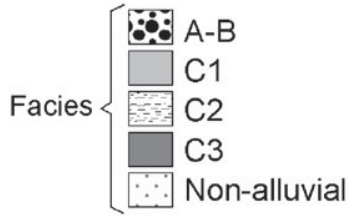

Fig. 8. Evolution of CIA values, relation $\mathrm{SiO}_{2} / \mathrm{TiO}_{2}$ and clay mineral composition throughout sections 6 and 7. Location of sections in Fig. 1.

consistent trend, but the higher kaolinite/illite relations at the top of unit U2B (Fig. 8) and the kaolinite content in unit U3 (Fig. 2) are also attributed to recycling processes. The expansion of the watersheds due to recessive erosion may explain the increase in the contribution of recycled sediments. As the previous cycle Cenozoic sediments are friable, contrasting with the underlying basement rocks, their erosion and incorporation in subsequent sedimentary deposits would be accomplished much more easily (Fig. 9).

Different alluvial fan catchment lithologies explain the spatially variable clast composition of unit U3 (Fig. 2). In the northern sectors the high staurolite and mica percentages in the heavy mineral assemblages suggest that these sediments were mainly derived from metasedimentary rocks of the uplifted Variscan Iberian Massif. Conversely, the high proportion of ultrastable heavy minerals (frequently rounded) and gravel-size clasts of silicified sandstones in the southern sectors indicate different provenance. The Cretaceous to lower Cenozoic silicified rocks, whose relicts are found over Ordovician-Silurian units, must have occupied part of these deposits catchment areas. Recycling was probably more effective in the SE sector due to the higher uplift during the previous phases of intense tectonic activity, making older sediments easily available to source Plio-Pleistocene units.

\section{Conclusions}

(1) The mineralogical and geochemical signals are partially determined by depositional conditions. Swamp-lake sediments usually have higher REE content (131-300 ppm) than floodplain sediments $(62-218 \mathrm{ppm})$; the differences between facies in HREE content are more pronounced (12-15 ppm in swamp-lake vs. 5-12 ppm in floodplain). Most REE in floodplain sediments is hosted in $\mathrm{Y}$ and Th-bearing minerals, but a significant part of the LREE must be associated with illite; other phases (e.g. organic matter) must be associated with REE in swamp-lake sediments.

(2) The integration of mineralogical (e.g. clay and heavy assemblages, illite crystallinity) and geochemical (e.g. evidences of $\mathrm{Mg}$ rich illite, resemblances between Plio-Pleistocene sediments and Variscan basement REE geochemistry) data indicate that the basin edge metapelitic rocks are major sediment sources and a significant part of the clay minerals are inherited from these rocks. This fact is attributed to depositions under tectonic active conditions.

(3) Sediment sourced from Variscan granitic rocks can have higher $\mathrm{Eu} / \mathrm{Eu}^{*}$ anomaly and lower $(\mathrm{Gd} / \mathrm{Yb})_{\mathrm{N}}$ ratios than those sourced from the Precambrian and Paleozoic pelitic rocks of the basin edge.

(4) Sediment derived from the older basin edge basement rocks (Precambrian of $\mathrm{CIZ}$ ) tend to have either lower $(\mathrm{Gd} / \mathrm{Yb})_{\mathrm{N}}$ or $(\mathrm{La} / \mathrm{Sm})_{\mathrm{N}}$ ratios than these rocks. Mineral weathering (e.g. monazite and illite) must have contributed to these changes in REE concentrations.

(5) Recycling processes are responsible for higher CIA and ratios kaolinite/illite and $\mathrm{SiO}_{2} / \mathrm{TiO}_{2}$ in younger sediments, when climatic conditions are expected to have evolved to less chemically aggressive.

(6) From the combination of geochemical and mineralogical data it is possible to recognize small-scale differences in provenance and their evolution. Provenance varied through time, comprising 3 phases (Fig. 9): (1) In an early phase (transition unit U2A-U2B) the area received important amounts of sediment from granitic rocks, namely from the hinterland. (2) During a phase of intense tectonic activity (responsible for the coastal range uplift) the drainage from the hinterland loses importance 


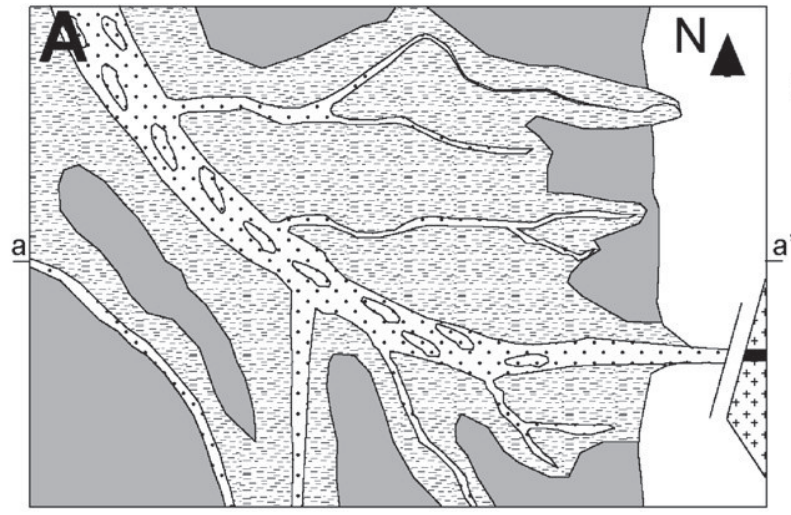

\section{Alluvial fan \\ Fluvial channel \\ Coastal fluv. channel \\ Floodplain \\ Lake-swamp}

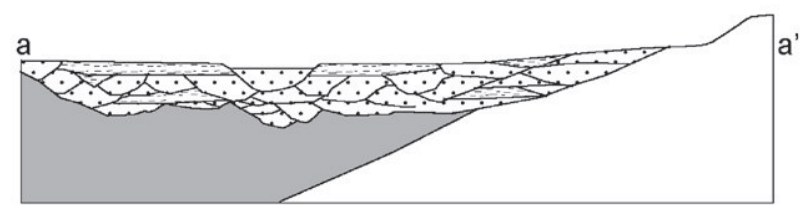

Major supply from hinterland (granitic rocks covered by Cenozoic-Mesozoic sedimentary units)
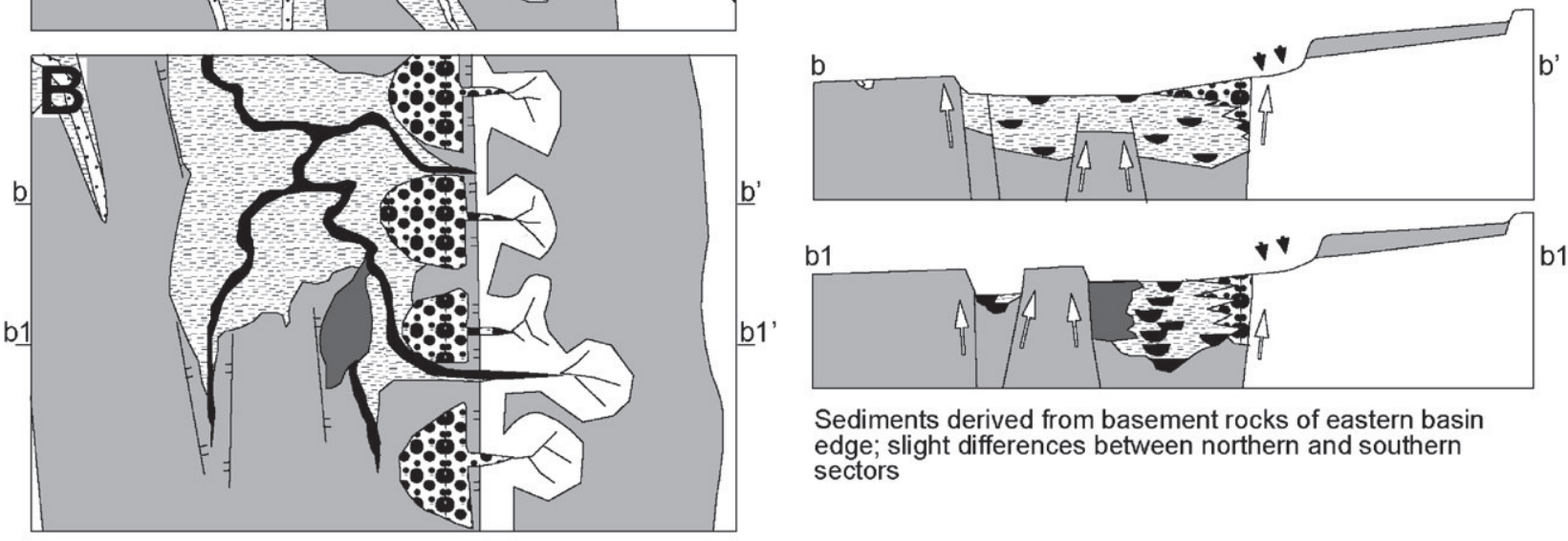

Sediments derived from basement rocks of eastern basin edge; slight differences between northern and southern sectors
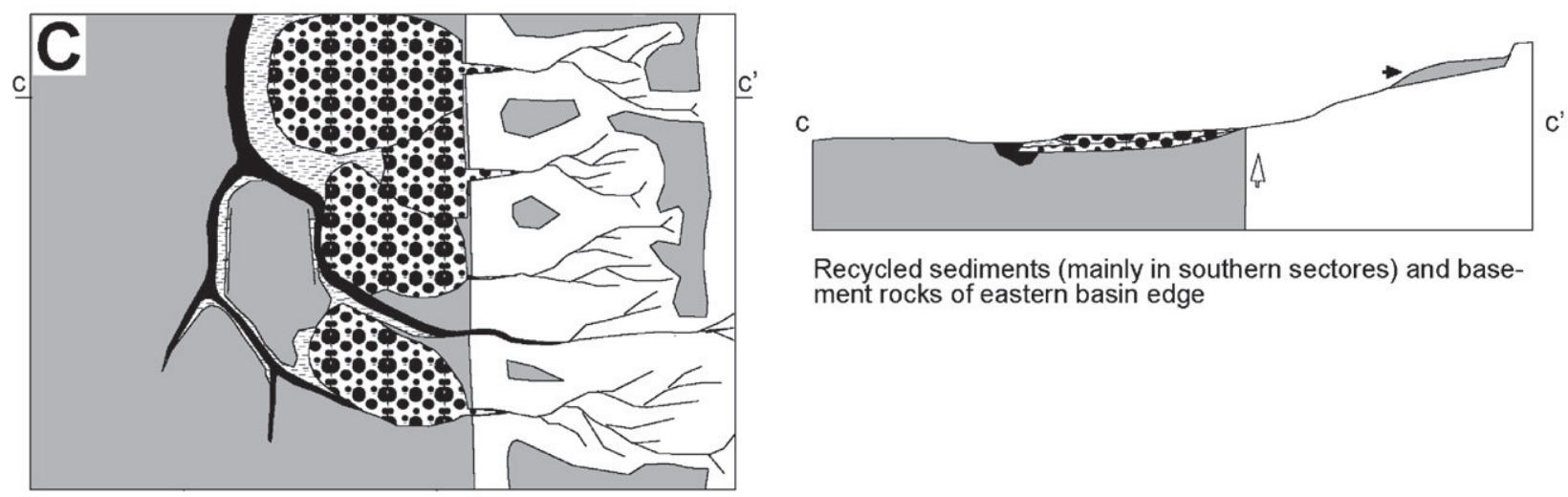

Recycled sediments (mainly in southern sectores) and basement rocks of eastern basin edge

Fig. 9. Phases of evolution of the alluvial system recorded by the upper part of unit U2A (A), unit U2B (B) and unit U3 (C). White arrows represent fault displacement. Black arrows indicate the proposed relative importance of downward or backward erosion in the source areas.

and the system provenance evolved to major lateral sediment input, supplied from the metapelitic rocks of the basin edge (unit U2B). By that time there was already a fluvial axis of northward drainage, but the system received relatively low proportion of sediment eroded and transported from the south. (3) Later phases (upper part of U2B and U3) are characterised by a progressive increase in the proportion of recycled Cretaceous and Cenozoic units as sediment sources. Recycling was probably particularly important in southern locations due to the more intense uplifting of their source areas.

\section{Acknowledgments}

We are grateful to Laboratório do INETI de S. Mamede Infesta, Porto, Portugal, where the chemical analysis were performed. The manuscript benefited from the critical comments of Stuart Gowland and an anonymous reviewer.

\section{References}

Aguado, B.V., Azevedo, M.R., Schaltegger, U., Catalán, J.M.R., Nolan, J., 2005. U-Pb zircon and monazite geochronology of Variscan magmatism related to synconvergence extension in Central Northern Portugal. Lithos 82, 169-184.

Aubert, D., Probst, A., Stille, P., 2004. Distribution and origin of major and trace elements (particularly REE, U and Th) into labile and residual phases in an acid soil profile (Vosges Mountains, France). Applied Geochemistry 19, 899-916.

Azevedo, M.R., Nolan, J., 1998. Hercynian late-post-tectonic granitic rocks from the Fornos de Algodres area (Northern Central Portugal). Lithos 44, 1-20.

Bauluz, B., Mayayo, M.J., Fernandez-Nieto, C., Lopez, J.M., 2000. Geochemistry of Precambrian and Paleozoic siliciclastic rocks from the Iberian Range (NE Spain): implications for source-area weathering, sorting, provenance, and tectonic setting. Chemical Geology 168, 135-150.

Braun, J.-J., Pagel, M., Herbillon, A., Rosin, C., 1993. Mobilization and redistribution of REES and Thorium in a syenitic lateritic profile - a mass balance study. Geochimica et Cosmochimica Acta 57, 4419-4434.

Cabral, J., 1995. Neotectónica em Portugal Continental. Memórias do Instituto Geológico e Mineiro 31, 1-265.

Cachão, M.A., 1989. Contribuição para o estudo do Pliocénico marinho português (sector Pombal Marinha Grande) - Micropaleontologia, biostratigrafia. MScequivalent Thesis. University of Lisbon, Lisbon, 204 pp.

Chaminé, H.I., Gama Pereira, L.C., Fonseca, P.E., Moço, L.P., Fernandes, J.P., Rocha, F.T., Flores, D., Pinto de Jesus, A., Gomes, C., Soares de Andrade, A.A., Araújo, A., 
2003. Tectonostratigraphy of Middle and Upper Palaeozoic black shales from the Porto-Tomar-Ferreira do Alentejo shear zone (W Portugal): new perspectives on the Iberian Massif. Geobios 36, 649-663.

Chamley, H., 1989. Clay Sedimentology. Springer-Verlag, Berlin, 623 pp.

Condie, K.C., Dengate, J., Cullers, R.L., 1995. Behavior of rare earth elements in a paleoweathering profile on granodiorite in the Front Range, Colorado, USA. Geochimica et Cosmochimica Acta 59, 279-294.

Corcoran, P.L., 2005. Recycling and chemical weathering in tectonically controlled Mesozoic-Cenozoic basins of New Zealand. Sedimentology 52, 757-774.

Cullers, R.L., Barret, T., Carlson, R., Robinson, B., 1987. Rare earth element and mineralogical changes in Holocene soil and stream sediment: a case study in the Wet Mountains, Colorado, USA. Chemical Geology 63, 275-295.

Cullers, R.L., Chaudhuri, S., Arnold, B., Lee, M., Wolf, C.W., 1975. Rare earth distributions in clay minerals and in the clay-sized fraction of the Lower Permian Havensville and Eskridge shales of Kansas and Oklahoma. Geochimica et Cosmochimica Acta 39, 1691-1703.

Cunha, P.M., Barbosa, B.P., Reis, R.P., 1993. Synthesis of the Piacenzian onshore record, between the Aveiro and Setúbal parallels (Western Portuguese margin). Ciências da Terra 12, 35-43.

Cunha, P.P., Martins, A.A., Pais, J., 2008. O estudo do Cenozóico em Portugal Continental: "estado da arte" e perspectivas futuras. In: Callapez, P.M., Rocha, R.B., Marques, J.F., Cunha, L.S., Dinis, P.M. (Eds.), A Terra: Conflitos e Ordem, Livro de Homenagem ao Professor Ferreira Soares,. University of Coimbra, pp. 101-110.

Dias, R., Ribeiro, A., 1993. Porto-Tomar shear zone, a major structure since the beginning of the variscan orogeny. Comunicações do Instituto Geológico e Mineiro 79, $31-40$.

Dinis, P.A., 2006. Depósitos neogénicos anteriores à incisão fluvial actual entre Coimbra e Aveiro: fácies, arquitectura deposicional e controlos sobre a sedimentação. Comunicações Geológicas 93, 81-104.

Dinis, P.A., Soares, A.F., 2007a. Controlling factors on clay mineral assemblages: insights from facies analysis of Pliocene to Pleistocene coastal margin deposits, Western Portugal. Geologica Acta 5, 177-193.

Dinis, P.A., Soares, A.F., 2007b. Stable and ultrastable heavy minerals of alluvial to nearshore marine sediments from Central Portugal: facies related trends. Sedimentary Geology 201, 1-20.

Diniz, F., 1984. Apports de la palynologie à la connaissance du Pliocène portugais. Rio Maior: un basin de référence pour lîhistoire de la flore, de la végétation et du climat de la façade atlantique de lǐEurope meridionale. PhD Thesis. Université des Sciences et Techniques de Languedoc, Montpellier, France, $230 \mathrm{pp}$.

Ferreira, A.B., 1991. Neotectonics in Northern portugal. A geomorpholigical approach. Zeitschrift fur Geomorph, v. Suppl. Bd. 82, 73-85.

Gingele, F.X., 1996. Holocene climatic optimum in Southwest Africa-evidence from the marine clay mineral record. Palaeogeography, Palaeoclimatology, Palaeocology $122,77-87$

Gotze, J., Lewis, R., 1994. Distribution of REE and trace elements in size and mineral fractions of high-purity quartz sands. Chemical Geology 114, 43-57.

Gu, X.X., Liu, J.M., Zheng, M.H., Tang, J.X., Qi, L., 2002. Provenance and tectonic setting of the Proterozoic turbidites in Hunan. South China: geochemical evidence. J. Sedimentary Research 72, 393-407.

Jonasson, R.G., Bancroft, G.M., Boatner, L.A., 1988. Surface reactions of syntetic, endmember analogues of monazite, xenotime and rhabdophane, and evolution of natural waters. Geochimica et Cosmochimica Acta 52, 767-770.

Kahle, M., Kleber, M., Jahn, R., 2002. Review of XRD-based quantitative analyses of clay minerals in soils: the suitability of mineral intensity factors. Geoderma 109, $191-205$
López, J.M.G., Bauluz, B., Fernández-Nieto, C., Oliete, A.Y.. 2005. Factors controlling the trace-element distribution in fine-grained rocks: the Albian kaolinite-rich deposits of the Oliete Basin (NE Spain). Chemical Geology 214, 1-19.

McLennan, S.M., 1989. Rare earth elements in sedimentary rocks: influence of provenance and sedimentary processes. Reviews in Mineralogy 21, 169-200.

McLennan, S.M., Hemming, S.R., McDaniel, D.K., Hanson, G.N., 1993. Geochemical approaches to sedimentation, provenance and tectonics. In: Johnsson, M.J., Basu, A. (Eds.), Processes Controlling the Composition of Clastic Sediments, vol. 284. Geological Society of America Special Paper, pp. 21-40.

Michaux, J., Suc, J.-P., Vernet, J.-L., 1979. Climatic inference from the history of the Taxodiaceae during the Pliocene and Early Pleistocene in Western Europe. Review of Paleobotany and Palynology 27, 185-191.

Morton, A.C., Hallsworth, C.R., 1999. Processes controlling composition of heavy mineral assemblages. Sedimentary Geology 124, 3-29.

Neiva, A.M. Williams, I.S., Ramos, J.M.F., Gomes, M.E.P., Silva, M.M.V.G Antunes, I.M.H.R., 2009. Geochemical and isotopic constraints on the petrogenesis of Early Ordovician granodiorite and Variscan two-mica granites from the Gouveia area, central Portugal. Lithos 111, 186-202.

Nesbitt, H., Young, G., 1982. Early Proterozoic climates and plate motions inferred from major element chemistry of lutites. Nature 299, 715-717.

Nesbitt, H., Markovics, G., 1997. Weathering of granodioritic crust, long-term storage of elements in weathering profiles, and paragenesis of siliciclastic sediments. Geochimica et Cosmochimica Acta 61, 1653-1670.

Pereira, L.C., 1987. Tipologia e evolução da sutura entre a ZCI e a ZOM no Sector entre Alvaiázere Figueiró-dos-Vinhos (Portugal central). PhD Thesis. University of Coimbra, $331 \mathrm{pp}$.

Roy, P.D., Smykatz-Klos, W., 2007. REE geochemistry of the recent playa sediments from the Thar Desert. India: an implication to playa sediment provenance. Chemie der Erde 67, 55-68.

Schultz, L.G., 1964. Quantitative interpretation of mineralogical composition from X-ray and chemical data for the Pierre Shale. U. S. Geol. Surv. Prof. Pa 391-400, $1-31$.

Silva, C.M., 2001. Gastrópodes pliocénicos de Portugal. Sistemática, paleobiologia, paleoecologia e paleobiogeografia. PhD Thesis. University of Lisbon.

Singh, P., 2009. Major, trace and REE geochemistry of the Ganga River sediments: influence of provenance and sedimentary processes. Chemical Geology 266, 242-255.

Suc, J.-P., Zagwijn, W.H., 1983. Plio-Pleistocene correlations between the northwestern Mediterranean region and northwestern Europe according to recent biostratigraphic and palaeoclimatic data. Boreas 12, 153-166.

Taylor, S.R., McLennan, S.M., 1985. The Continental Crust: Its Composition and Evolution. Blackwell Scientific Publication, Oxford, 312 pp.

Thorez, J., 1976. Practical Identification of Clay Minerals. A Handbook for Teachers and Students in Clay Mineralogy. G. Lelotte, Dison, Belgique, 90 pp.

Tripathi, J.K., Ghazanfari, P., Rajamani, V., Tandon, S.K., 2007. Geochemistry of sediments of the Ganges alluvial plains: Evidence of large-scale sediment recycling. Quaternary International 159, 119-130.

Vieira, M.C.M., 2009. Palinologia do Pliocénico da Orla Ocidental Norte e Centro de Portugal: contributo para a compreensão da cronostratigrafia e da evolução paleoambiental, PhD Thesis. University of Minho, Braga, $336 \mathrm{pp}$.

Xu, Z., Han, G., 2009. Rare earth elements (REE) of dissolved and suspended loads in the Xijiang River, South China. Applied Geochemistry 24, 1803-1816. 